\title{
Multi-functional feedforward inhibitory circuits for cortical odor processing
}

\author{
Norimitsu Suzuki ${ }^{1}$, Malinda L. S. Tantirigama ${ }^{1,2}$, Helena H.-Y. Huang ${ }^{1}$ and \\ John M. Bekkers ${ }^{1 *}$
}

\begin{abstract}
${ }^{1}$ Eccles Institute of Neuroscience, John Curtin School of Medical Research, The Australian National University, Canberra, ACT 2601, Australia; ${ }^{2}$ Institut für Biologie, Neurocure Center for Excellence, Charité Universitätsmedizin Berlin and Humboldt Universität, Berlin, Germany
\end{abstract}

\author{
*For correspondence: \\ John M. Bekkers \\ Eccles Institute of Neuroscience \\ John Curtin School of Medical Research \\ The Australian National University \\ 131 Garran Road \\ Canberra, ACT 2601 \\ Australia \\ Email: John.Bekkers@anu.edu.au
}


bioRxiv preprint doi: https://doi.org/10.1101/2021.09.19.460974; this version posted September 19, 2021. The copyright holder for this

preprint (which was not certified by peer review) is the author/funder, who has granted bioRxiv a license to display the preprint in perpetuity. It is made available under aCC-BY 4.0 International license.

Suzuki et al - p 2

\section{Abstract}

2 Feedforward inhibitory circuits are key contributors to the complex interplay between

3 excitation and inhibition in the brain. Little is known about the function of feedforward

4 inhibition in the primary olfactory (piriform) cortex. Using in vivo two-photon targeted

5 patch clamping and calcium imaging in mice, we find that odors evoke strong excitation

6 in two classes of interneurons - neurogliaform (NG) cells and horizontal (HZ) cells -

7 that provide feedforward inhibition in layer 1 of the piriform cortex. NG cells fire much

8 earlier than HZ cells following odor onset, a difference that can be attributed to the

9 faster odor-driven excitatory synaptic drive that NG cells receive from the olfactory

10 bulb. As a consequence, NG cells strongly but transiently inhibit odor-evoked

11 excitation in layer 2 principal cells, whereas HZ cells provide more diffuse and

12 prolonged feedforward inhibition. Our findings reveal unexpected complexity in the

13 operation of inhibition in the piriform cortex. 
Suzuki et al - p 3

\section{Introduction}

Synaptic inhibition in the cortex is an intricate process with many interacting parts. Cortical interneurons are classified into dozens of subtypes with distinctive morphological, transcriptomic and electrophysiological properties (Kawaguchi and Kubota, 1997; Tremblay et al., 2016; Zeng and Sanes, 2017; Gouwens et al., 2020). These diverse interneurons are embedded in at least three types of cortical inhibitory circuits - feedforward inhibition, feedback inhibition and disinhibition (Kullmann and Lamsa, 2007; Isaacson and Scanziani, 2011; Denève and Machens, 2016; Tremblay et al., 2016; Lourenco et al., 2020). Within these three categories there exist numerous variants that implement a variety of neural computations. For example, feedforward and feedback inhibition exert different effects depending on whether the effector interneurons innervate the perisomatic or distal dendritic regions of their targets (Bruno and Sakmann, 2006; Isaacson and Scanziani, 2011; Pardi et al., 2020), and disinhibition can depend on the subtypes of interneurons involved and the origin of their inputs (Pi et al., 2013; Fu et al., 2014; Tremblay et al., 2016). In this paper we focus on feedforward inhibition in the primary olfactory (piriform) cortex, and report that a surprising complexity of inhibitory processing is also a feature of this type of inhibition in the paleocortex.

Feedforward inhibition is conventionally understood as an input-tracking mechanism that does not depend on local circuit activity (Tremblay et al., 2016). In the primary neocortex, feedforward inhibition is often mediated by parvalbuminexpressing fast-spiking basket cells localized in the deeper layers that receive direct afferent input from first-order thalamic nuclei (Beierlein et al., 2003; Gabernet et al., 2005; Cruikshank et al., 2007). In this role feedforward inhibition improves sensory discrimination by favoring coincidence detection, but in addition it can provide gain 
bioRxiv preprint doi: https://doi.org/10.1101/2021.09.19.460974; this version posted September 19, 2021. The copyright holder for this preprint (which was not certified by peer review) is the author/funder, who has granted bioRxiv a license to display the preprint in perpetuity. It is made available under aCC-BY 4.0 International license.

Suzuki et al - p 4

modulation through input normalization (Bruno and Sakmann, 2006; Carandini and Heeger, 2011). More recently it has been reported that feedforward inhibition is also prominent in layer 1 of the neocortex, where it can engage afferent input from other cortical regions and from higher-order thalamic nuclei (Pardi et al., 2020; Anastasiades et al., 2021). However, the properties and functions of layer 1 neocortical interneurons have received relatively little attention and remain enigmatic (Schuman et al., 2019; Fan et al., 2020; Lourenco et al., 2020).

The piriform cortex $(\mathrm{PCx})$ is unusual in that it receives all of its primary afferent input from the olfactory bulb into the superficial part of layer 1 (layer 1a; Neville and Haberly, 2004; Bekkers and Suzuki, 2013). Layer 1a mostly contains the apical dendrites of glutamatergic principal cells located in layers 2 and 3, as well as the somas, axons and dendrites of two classes of GABAergic interneurons, namely, neurogliaform (NG) cells and horizontal (HZ) cells (Suzuki and Bekkers, 2010a). NG and HZ cells in layer 1a are thus ideally situated to provide feedforward inhibition onto the distal dendrites of layer 2/3 principal cells. Classic work (Biedenbach and Stevens, 1969; Haberly, 1973), as well as more recent studies (e.g. Luna and Schoppa, 2008; Stokes and Isaacson, 2010; Suzuki and Bekkers, 2012; Sheridan et al., 2014; Stokes et al., 2014; Large et al., 2016a; Large et al., 2016b), have used electrical stimulation to explore some of the basic properties of feedforward inhibition in the PCx. However, less is known about how particular types of interneurons respond to odor stimulation. The existence and importance of odor-evoked inhibition in the $\mathrm{PCx}$ has been established (Poo and Isaacson, 2009; Zhan and Luo, 2010; Franks et al., 2011; Poo and Isaacson, 2011; Sturgill and Isaacson, 2015; Bolding and Franks, 2017; Tantirigama et al., 2017; Bolding and Franks, 2018) but the identities and properties of neurons responsible for the different kinds of inhibition are, for the most part, uncertain. 
bioRxiv preprint doi: https://doi.org/10.1101/2021.09.19.460974; this version posted September 19, 2021. The copyright holder for this preprint (which was not certified by peer review) is the author/funder, who has granted bioRxiv a license to display the preprint in perpetuity. It is made available under aCC-BY 4.0 International license.

Suzuki et al - p 5

Here we approach this question by using 2-photon targeted whole-cell patch clamping and functional $\mathrm{Ca}^{2+}$ imaging to record from visually identified $\mathrm{NG}$ and $\mathrm{HZ}$ cells in layer la of the PCx in vivo. We find that the odor-evoked feedforward inhibition provided by these two types of interneurons is strikingly different: NG cells express a powerful and transient inhibition that begins rapidly after odor onset, whereas $\mathrm{HZ}$ cells provide a more diffuse and delayed form of feedforward inhibition. Thus, a multifunctional feedforward inhibitory circuit exists in the superficial layer of the PCx, where it is well-placed to generate dynamically complex patterns of inhibition in the distal dendrites of principal cells.

\section{Results}

Interneurons that provide feedforward inhibition in the PCx can be targeted 'in vivo'

in isolation only those neural circuits that generate feedforward synaptic inhibition.

Afferent input from the olfactory bulb via the lateral olfactory tract (LOT) to the PCx is strictly confined to layer 1a (L1a) of the PCx (Figure 1A; Neville and Haberly, 2004). Hence, only those interneurons with dendrites concentrated in L1a, where they are able to intercept axons from the LOT, are able to generate feedforward inhibition (red cells, Figure 1A). Two such interneuron types have been identified in the PCx, HZ cells and L1a NG cells (Suzuki and Bekkers, 2010a). Conversely, feedback inhibition is largely mediated by interneurons with dendrites concentrated in deeper associational layers, two prominent types being fast-spiking (FS) and regular-spiking (RS) interneurons (blue cells, Figure 1A). In this paper we focus on the feedforward inhibitory neurons, HZ cells and L1a NG cells (here called 'NG cells' for short), located in the anterior PCx. 
bioRxiv preprint doi: https://doi.org/10.1101/2021.09.19.460974; this version posted September 19, 2021. The copyright holder for this preprint (which was not certified by peer review) is the author/funder, who has granted bioRxiv a license to display the preprint in perpetuity. It is made available under aCC-BY 4.0 International license.

Suzuki et al - p 6

A

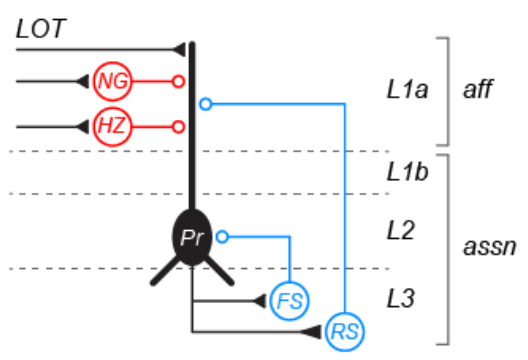

C

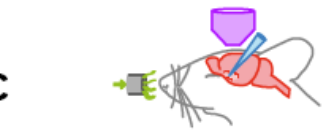

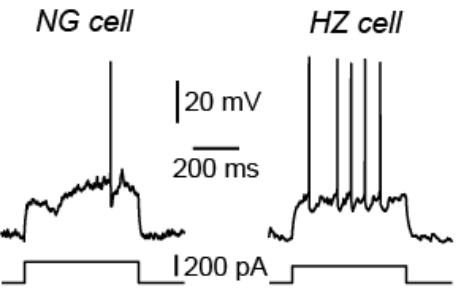

E NG cell

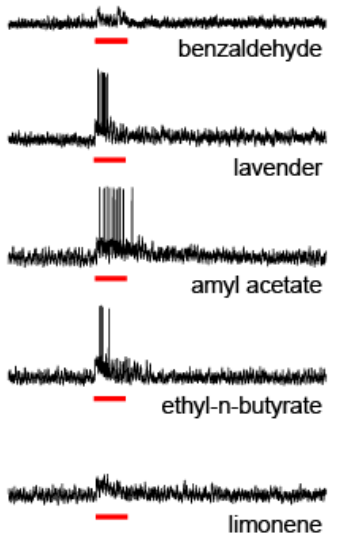

F $\mathrm{HZ}$ cell
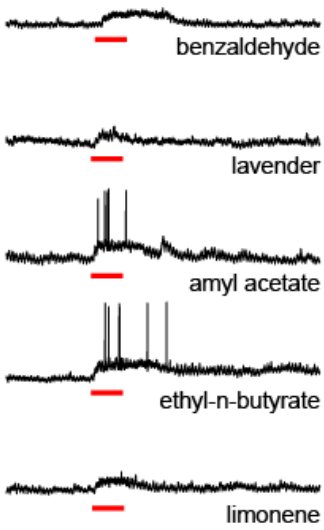

B
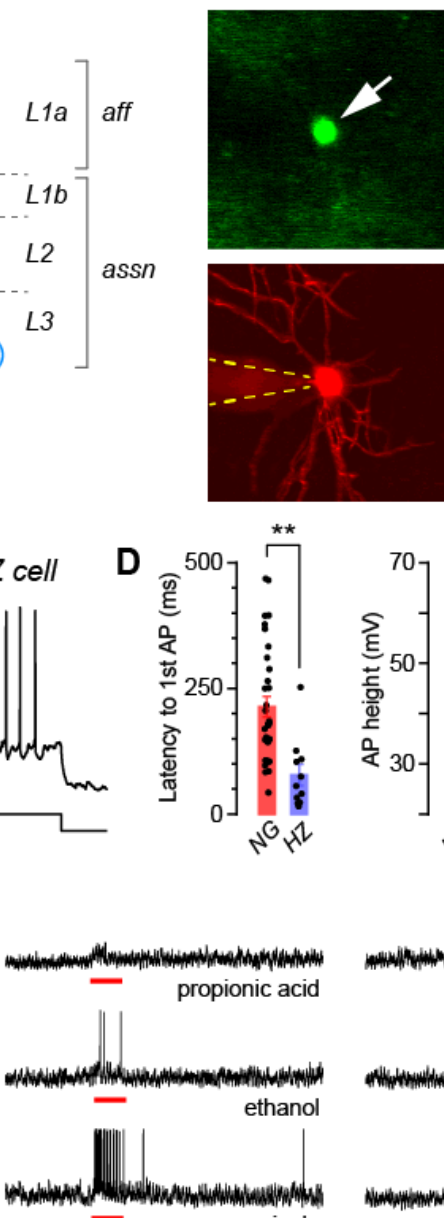

anisole
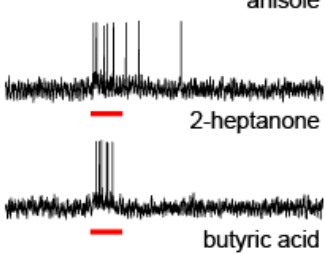

$50 \mathrm{mV}$
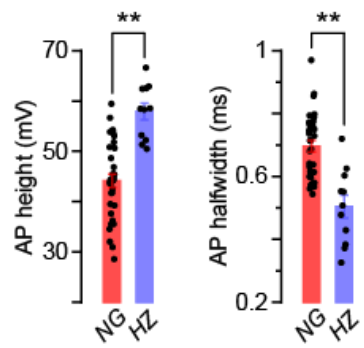

$H Z$ cell
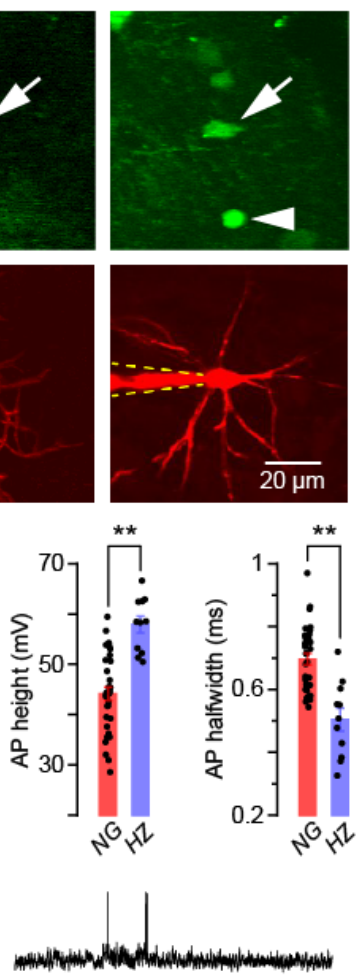

isoamyl acetate

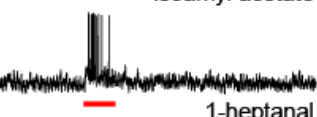

1-heptanal

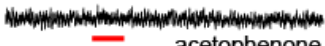

acetophenone
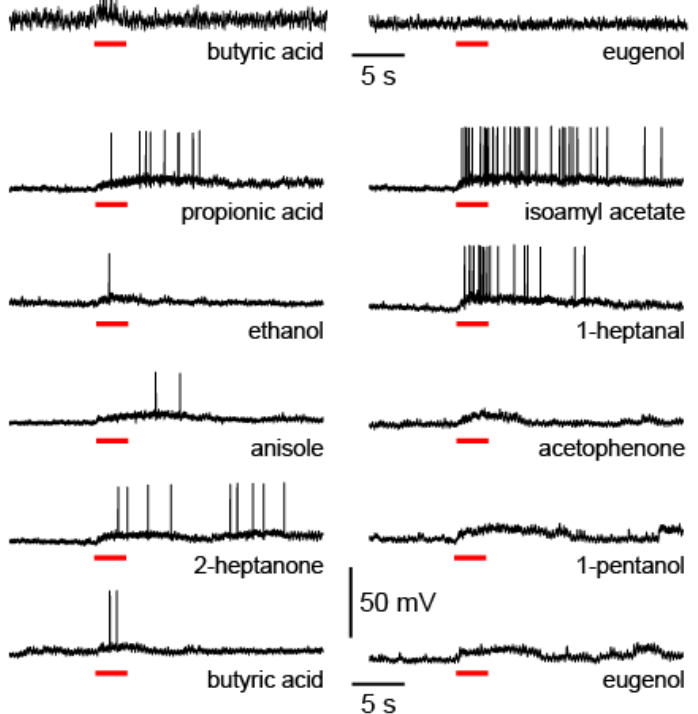

Figure 1. Layer 1a neurogliaform (NG) and horizontal $(\mathrm{HZ})$ cells are reliably distinguished using two-photon-targeted patch clamping in vivo. $N G$ and $\mathrm{HZ}$ cells respond differently to odors. 
bioRxiv preprint doi: https://doi.org/10.1101/2021.09.19.460974; this version posted September 19, 2021. The copyright holder for this preprint (which was not certified by peer review) is the author/funder, who has granted bioRxiv a license to display the preprint in perpetuity. It is made available under aCC-BY 4.0 International license.

Suzuki et al - p 7

Pair recordings in slices show that all types of interneurons in the anterior $\mathrm{PCx}$ synaptically inhibit principal cells (Figure 1A; Suzuki and Bekkers, 2010a; Suzuki and Bekkers, 2012). Inhibition is commonly observed at the soma of principal cells in response to odors in vivo (e.g. Poo and Isaacson, 2009; Zhan and Luo, 2010; Franks et al., 2011; Tantirigama et al., 2017; Bolding and Franks, 2018), although it is not immediately clear whether this inhibition is dominated by feedforward or feedback inhibitory circuits. We decided to explore feedforward inhibition in this study because the relevant interneurons ( $\mathrm{NG}$ and $\mathrm{HZ}$ cells) are close to the cortical surface and more readily accessible to 2-photon targeted patch clamping in vivo. are distributed throughout L1a; HZ cell somata have an elongated shape whereas NG

103 somata are spherical; and HZ cells express much lower levels of GFP than NG cells

104 (Figure 1B, top; Suzuki and Bekkers, 2010a; Suzuki and Bekkers, 2010b). After wholecell recording, their identities could be confirmed by their dendritic morphology (NG: short, thin, highly branched dendrites; HZ: longer, less branched, often spiny; Figure $1 \mathrm{~B}$, bottom) and distinctive intrinsic electrical properties (Figure 1C, D), similar to in 108 vitro (Suzuki and Bekkers, 2010a). Thus, we were confident that we could record from 109 identified NG and HZ cells in vivo.

\section{$N G$ and $H Z$ cells respond strongly to odors}

We applied up to 15 odorants from a variety of chemical functional groups to

113 urethane-anesthetized mice and measured the voltage responses of identified NG and

$114 \mathrm{HZ}$ cells in the anterior PCx (Figure 1E, F). Three features were apparent in these 
bioRxiv preprint doi: https://doi.org/10.1101/2021.09.19.460974; this version posted September 19, 2021. The copyright holder for this preprint (which was not certified by peer review) is the author/funder, who has granted bioRxiv a license to display the preprint in perpetuity. It is made available under aCC-BY 4.0 International license.

Suzuki et al - p 8

116 broadly tuned); second, regular oscillations in the membrane potential $\left(V_{m}\right)$ often

117 became larger in the presence of odor; and third, HZ cells appeared to respond more

118 slowly to odors than did NG cells. Each of these features is examined in the following 119 sections.

120

NG and HZ cells are broadly excited by odors

Our palette of odorants was drawn from a variety of chemical functional groups intended to span a large part of 'odor space' (although this term is difficult to define;

124 Pashkovski et al., 2020; Ravia et al., 2020). We measured odor responsiveness by 125 median-filtering each trace to remove action potentials (APs) then testing whether the $126 \mathrm{z}$-scored $V_{m}$ amplitude exceeded a positive threshold during the period of odor 127 application (Experimental Procedures; Figure 1 - Figure Supplement 1). These data 128 were analyzed in two different ways: (i) by calculating the fraction of odors that each 129 cell responded to, then averaging across cells ('cell-averaged index'); and (ii) by 130 calculating the fraction of cells each odor activated, then averaging across odors ('odor131 averaged index'). NG and HZ cells both had large cell-averaged indices that were not 132 significantly different from each other (NG: $0.78 \pm 0.04, n=28$ cells; HZ: $0.66 \pm 0.12$, $133 n=9 ; p=0.34$, Welch's 2-sample unpaired t-test). The odor-averaged index was also

134 large for both cell types but was significantly smaller for HZ cells (NG: $0.75 \pm 0.03$, $135 n=15$ odors; HZ: $0.60 \pm 0.06, n=15 ; p=0.025$, Welch's 2-sample unpaired t-test).

136 Similar results were found by using an alternative pair of measures, the lifetime and 137 population sparseness, which are analogous to the cell- and odor-averaged indices, 138 respectively (Willmore and Tolhurst, 2001; Poo and Isaacson, 2009). 
bioRxiv preprint doi: https://doi.org/10.1101/2021.09.19.460974; this version posted September $19,2021$. The copyright holder for this preprint (which was not certified by peer review) is the author/funder, who has granted bioRxiv a license to display the preprint in perpetuity. It is made available under aCC-BY 4.0 International license.

Suzuki et al - p 9

\section{Respiration-locked oscillations in $V_{m}$ are prominent in $N G$ and $H Z$ cells}

Subthreshold oscillations in $V_{m}$ were frequently seen in both NG and HZ cells (e.g. Figures $2 \mathrm{~A}$ and $2 \mathrm{~B}$, top, show the same cells as in Figures $1 \mathrm{E}$ and $1 \mathrm{~F}$ responding to ethyl-n-butyrate; gray traces are respiration, with upward spikes indicating onset of exhalation). Expanding the traces in windows before $(b)$, during $(d)$ and after $(a)$ odor application revealed that oscillations in $V_{m}$ were synchronized to respiration and, at least

A

NG cell
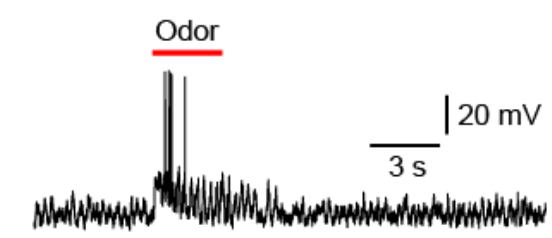

umm.
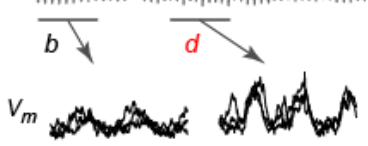

Resp A M A A Mand

C
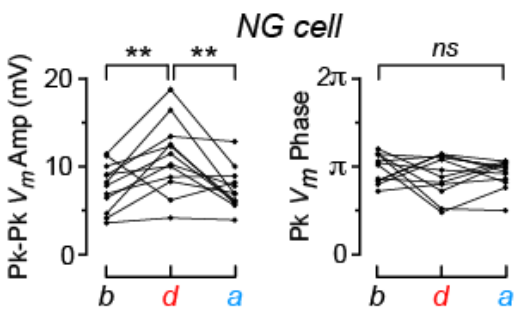

B

HZ cell

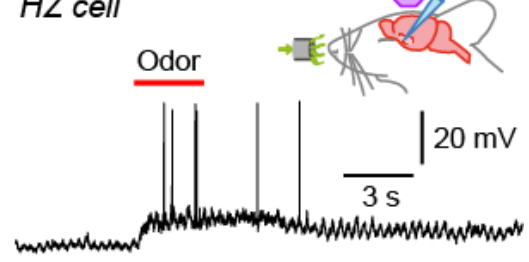

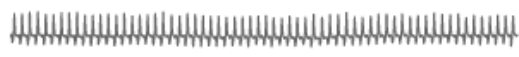

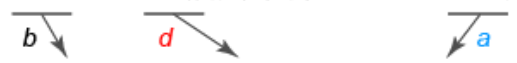

$40 \mathrm{mV}$

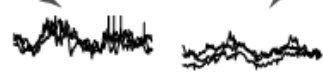

$20 \mathrm{mV}$

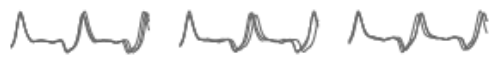

Figure 2. Oscillations in membrane potential $\left(V_{m}\right)$ are synchronized to respiration in NG and $\mathrm{HZ}$ cells, and the oscillation amplitude is enhanced in NG cells during odors.

146 in the NG cell, the amplitude of $V_{m}$ oscillations appeared to increase during the odor

147 (Figures 2A and 2B, bottom). These observations were quantified by excising the

148 segments of $V_{m}$ that lay between successive positive peaks of the respiration trace,

149 linearly warping them to have the same time axis, then averaging together all such

150 segments within each of the three windows $(b, d, a)$ for each odor. The peak-to-peak

151 amplitude of the average $V_{m}$ and the time of the positive peak of average $V_{m}$, expressed 
153 each triplet of connected points is from each odor; only the data from the NG cell in

154 Figure 2A are shown). For this particular NG cell, the peak-to-peak $V_{m}$ amplitude

155 increased significantly during the odor $(b: 7.7 \pm 0.8 \mathrm{mV} ; d: 11.1 \pm 1.2 \mathrm{mV} ; n=12, p=$

1560.002 , 1-way ANOVA with Tukey contrasts), whereas the phase of the peak was

157 unchanged $(b: 0.49 \pm 0.02 ; d: 0.45 \pm 0.03$, both expressed as a fraction of the respiration 158 cycle; $p=0.47)$.

159 A similar analysis was done for all NG and HZ cells in our dataset and the 160 summary is shown in Figure 2D. The mean peak-to-peak $V_{m}$ amplitude increased 161 significantly during odors in NG cells but not in HZ cells (Figure 2D, left; $n=232$ trials 162 in $22 \mathrm{NG}$ cells, $p<0.0002 ; n=99$ trials in $10 \mathrm{HZ}$ cells, $p=0.78$; 1 -way ANOVA with

163 Tukey). In contrast, the phase of the peak $V_{m}$ was unchanged by odors in both NG and $164 \mathrm{HZ}$ cells (Figure 2D, right). The same result was obtained if we used a different 165 measure of phase-locking between $V_{m}$ and respiration, the cross-covariance (Figure 2 -

166 Figure Supplement 1). Thus, while NG and HZ cells both show strong respiration167 coupled oscillations in their sub-threshold $V_{m}$, odors affected these cells differently: in $168 \mathrm{NG}$ cells the oscillation amplitude increased, whereas in $\mathrm{HZ}$ cells $V_{m}$ tended to 169 depolarize without a change in the oscillation.

170 We wondered if the oscillations in $V_{m}$ we found in NG (and HZ) cells in the PCx 171 were also seen in NG cells in other cortical areas and, if so, whether they were 172 synchronized to respiration. We made targeted whole-cell recordings from NG cells in 173 the upper layers of primary somatosensory cortex in vivo and found that, although $V_{m}$ 174 oscillations were strongly present, their temporal structure was different from those in 175 PCx and they were not synchronized to respiration (Figure 2 - Figure Supplement 2). 
bioRxiv preprint doi: https://doi.org/10.1101/2021.09.19.460974; this version posted September $19,2021$. The copyright holder for this

preprint (which was not certified by peer review) is the author/funder, who has granted bioRxiv a license to display the preprint in perpetuity. It is made available under aCC-BY 4.0 International license.

Suzuki et al - p 11

\section{NG and HZ cells tend to fire early and late, respectively, following odor onset}

Next, we turned to the apparent difference in the kinetics of the odor response, with NG cells appearing to be excited more quickly following odor application (Figures $1 \mathrm{E}$ and $1 \mathrm{~F})$. We confirmed this impression by constructing AP raster plots and peristimulus time histograms (Figure 3A): spiking in NG cells reached a peak at $0.43 \pm$ $0.14 \mathrm{~s}$ after odor onset ( $n=7$ cells), whereas in HZ cells the peak occurred at $1.92 \pm$ $0.24 \mathrm{~s}(n=5$ cells; significantly different, $p=0.0013$, Welch's 2-sample unpaired ttest). Control experiments confirmed that none of these responses were limited by the rate of delivery of odorants by our olfactometer (Figure 3 - Figure Supplement 1).

A NG cell

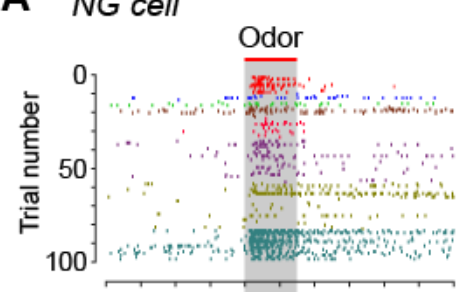

$H Z$ cell

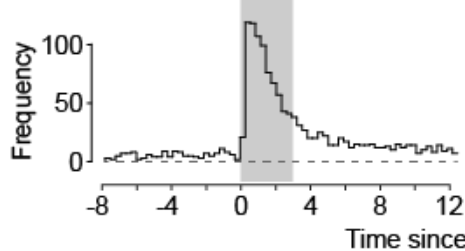

Time since odor onset (s)

B

NG cell
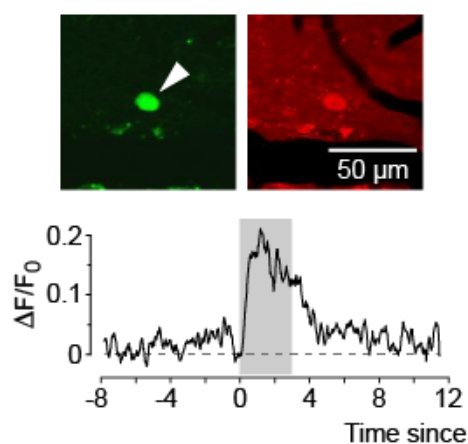

Time since odor onset (s)

Figure 3. NG cells tend to fire earlier than $\mathrm{HZ}$ cells in response to odors.
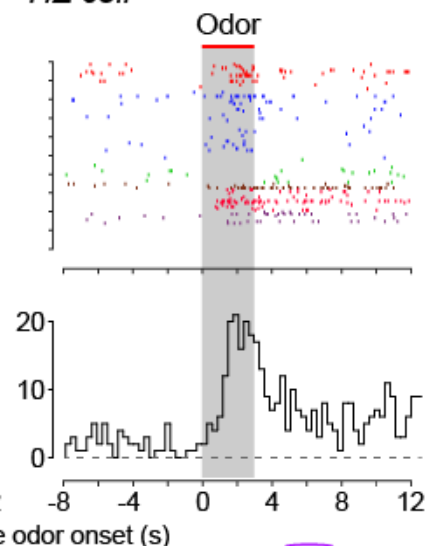

$H Z$ cell
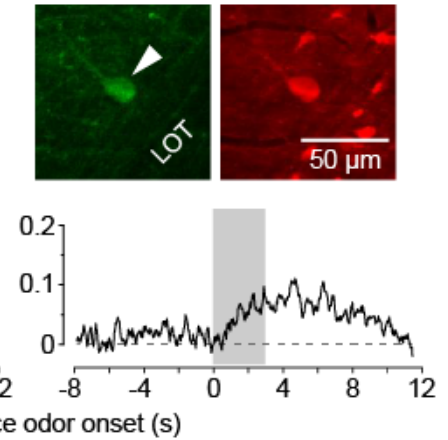
187 invasive approach, we turned to 2-photon $\mathrm{Ca}^{2+}$ imaging with the red-shifted indicator

Cal-590. NG and HZ cells could be distinguished as before from their soma location, soma shape and GFP fluorescence (Figure 3B, top), and odor-evoked spiking could be resolved from changes in $\Delta \mathrm{F} / \mathrm{F}_{0}$ (Figure $3 \mathrm{~B}$, bottom). Consistent with whole-cell patch

191 clamping (Figure 3A), $\mathrm{Ca}^{2+}$ imaging showed that $\mathrm{NG}$ cells fired quickly after odor onset 192 and HZ cells fired with a delay (Figure 3B; traces are averages of $n=6 \mathrm{NG}$ cells and $193 n=5 \mathrm{HZ}$ cells; individual traces were too noisy to reliably determine the average time 194 to peak).

We also took advantage of the $\mathrm{Ca}^{2+}$ imaging approach to examine the effect of anesthetics on this neural circuit. (Because the surgery to expose the PCx is so invasive,

197 our experiments could not use awake animals.) All of the above experiments used 198 urethane $(0.7 \mathrm{~g} / \mathrm{kg})$. We repeated the imaging experiment in Figure 3B using fentanyl 199 plus medetomidine, which has been used to induce a more awake-like state of anesthesia (Constantinople and Bruno, 2011; Altwegg-Boussac et al., 2014). The result was the same (Figure 3 - Figure Supplement 2): in response to odors, NG cells fired early, HZ cells late. These findings, together with a report that urethane at the relatively

203 low concentration we used here has little effect on ligand-gated synaptic receptors 204 (Hara and Harris, 2002), suggest that the different odor-response dynamics of NG and HZ cells are not related to anesthesia.

\section{Different kinetics of odor-evoked EPSPs and EPSCs in NG and HZ cells}

Having found that NG and $\mathrm{HZ}$ cells differ in their AP responses to odors, we next 209 asked whether similar differences could be observed in the underlying EPSPs and 
$2112-4 \mathrm{~Hz}$ to remove respiration-coupled oscillations, then all EPSPs measured in the same

212 cell for different odors were averaged together (responses to 4-15 odors per cell; Figure

2134 -Figure Supplement 1). Because these averages were still relatively noisy (Figure 4

214 - Figure Supplement 1), a smooth curve (Methods) was fitted to each averaged EPSP 215 and the key parameters were measured from this curve. The analysis showed that odor216 evoked EPSPs reached their peak about 2-fold faster in NG cells than in HZ cells 217 (Figure 4A; NG: $0.53 \pm 0.05 \mathrm{~s}, n=16$ cells; HZ: $1.26 \pm 0.26 \mathrm{~s}, n=6$ cells; $p=0.038$, 218 unpaired t-test). Thus, the slower-rising EPSPs in HZ cells (Figure 4A) can explain the 219 longer delay to firing of these cells (Figure 3).

220 To confirm this result, we used a different method that focused on the rising phase 221 of individual, unaveraged EPSPs. Traces were again median-filtered to remove APs, 222 then the z-scored mean $V_{m}$ for each respiration cycle was plotted versus time and a 223 straight line was fitted over the period of odor application (Figure 4B; typical NG cell 224 on left, HZ cell on right). The slope of this line tended to be negative for NG cells and 225 positive for $\mathrm{HZ}$ cells (red and blue line, respectively; Figure 4B, bottom). These data were quantified for all odors and cells by plotting the peak z-scored $V_{m}$ amplitude during 227 the odor period versus the fitted slope (Figure 4C, top; NG cells in red, $n=310$ trials; 228 HZ cells in blue, $n=188$ trials). Trials that did not give an odor response (i.e. with 229 peak z-scored $V_{m}$ values $\leq 2.5$ ) are grayed out (Figure 4C, top). Histograms of all the 230 remaining trials confirm that the EPSP slopes for NG and HZ cells were significantly 231 different (Figure 4C, bottom; NG slope, $-0.27 \pm 0.02, n=232$ trials above the z-score 232 threshold; HZ slope, $0.21 \pm 0.04, n=84$ trials above threshold; $p<0.001$, Kolmogorov233 Smirnov [KS] test). Thus, during odors, EPSPs in NG cells tend to decline from an 234 early peak while EPSPs in HZ cells tend to rise to a later peak. These behaviors are 235 consistent with the odor-evoked AP firing observed in NG and HZ cells (Figure 3). 
A

NG cell
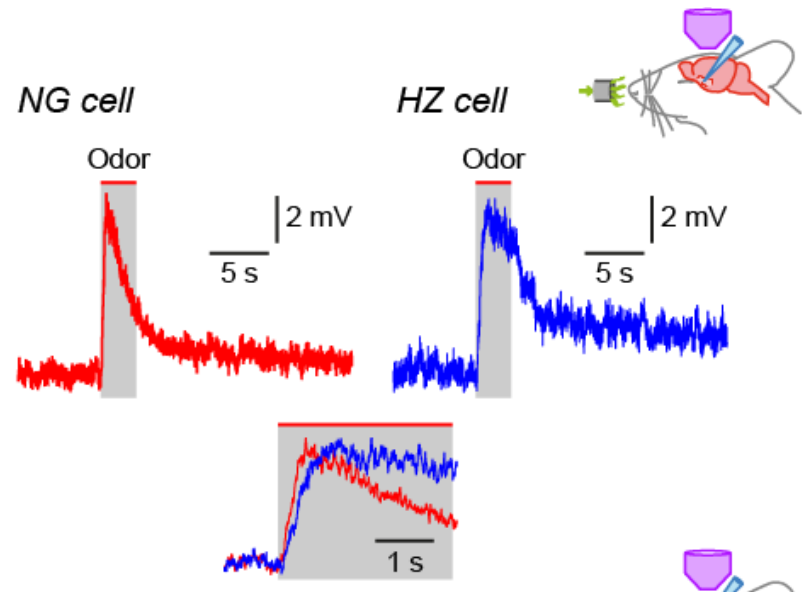

B

NG cell

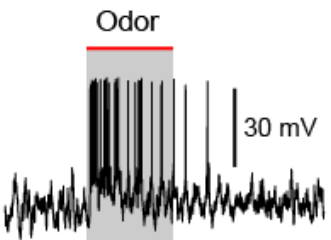

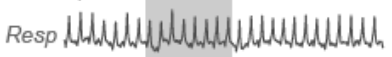

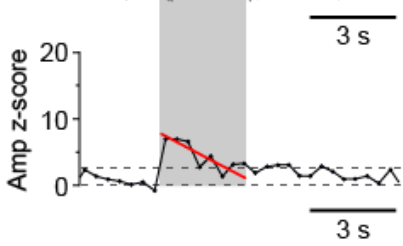

C
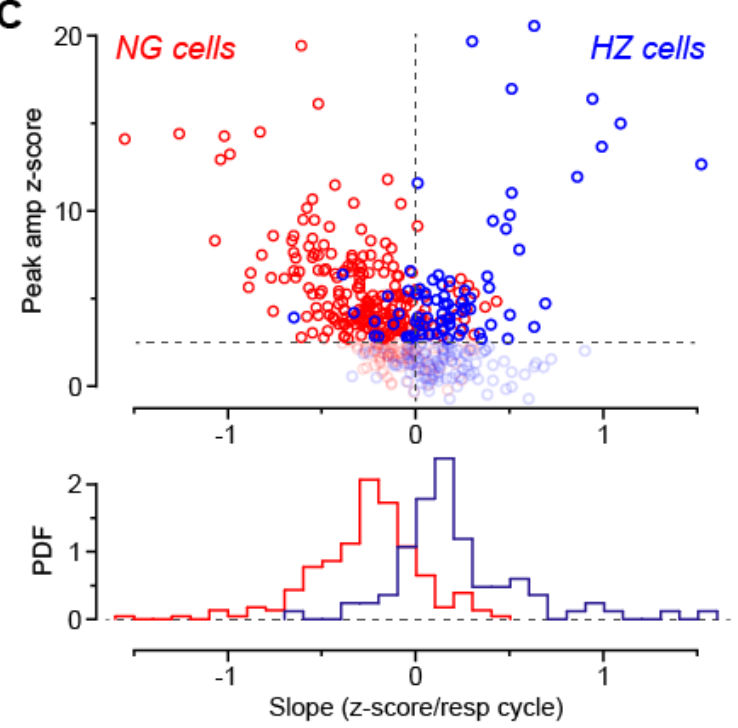

Figure 4. Odors cause $V_{m}$ to depolarize more slowly in $\mathrm{HZ}$ cells than in NG cells. 
bioRxiv preprint doi: https://doi.org/10.1101/2021.09.19.460974; this version posted September 19, 2021. The copyright holder for this

preprint (which was not certified by peer review) is the author/funder, who has granted bioRxiv a license to display the preprint in perpetuity. It is made available under aCC-BY 4.0 International license.

Suzuki et al - p 15

Differences in excitatory synaptic input can explain the odor response differences

between NG and $\mathrm{HZ}$ cells

What cellular mechanisms might explain the different odor response dynamics of

240 NG and HZ cells? Perhaps the simplest explanation is that NG cells receive depressing

241 EPSPs from the olfactory bulb via the LOT, whereas HZ cells receive facilitating

242 EPSPs (Figure 5A). To test this idea, we first recorded from NG and HZ cells in slices

243 and applied patterned electrical stimuli to the LOT. For brief trains of stimuli (6 pulses

244 at $40 \mathrm{~Hz}$, modeled on in vivo patterns; Suzuki and Bekkers, 2006), the response was the

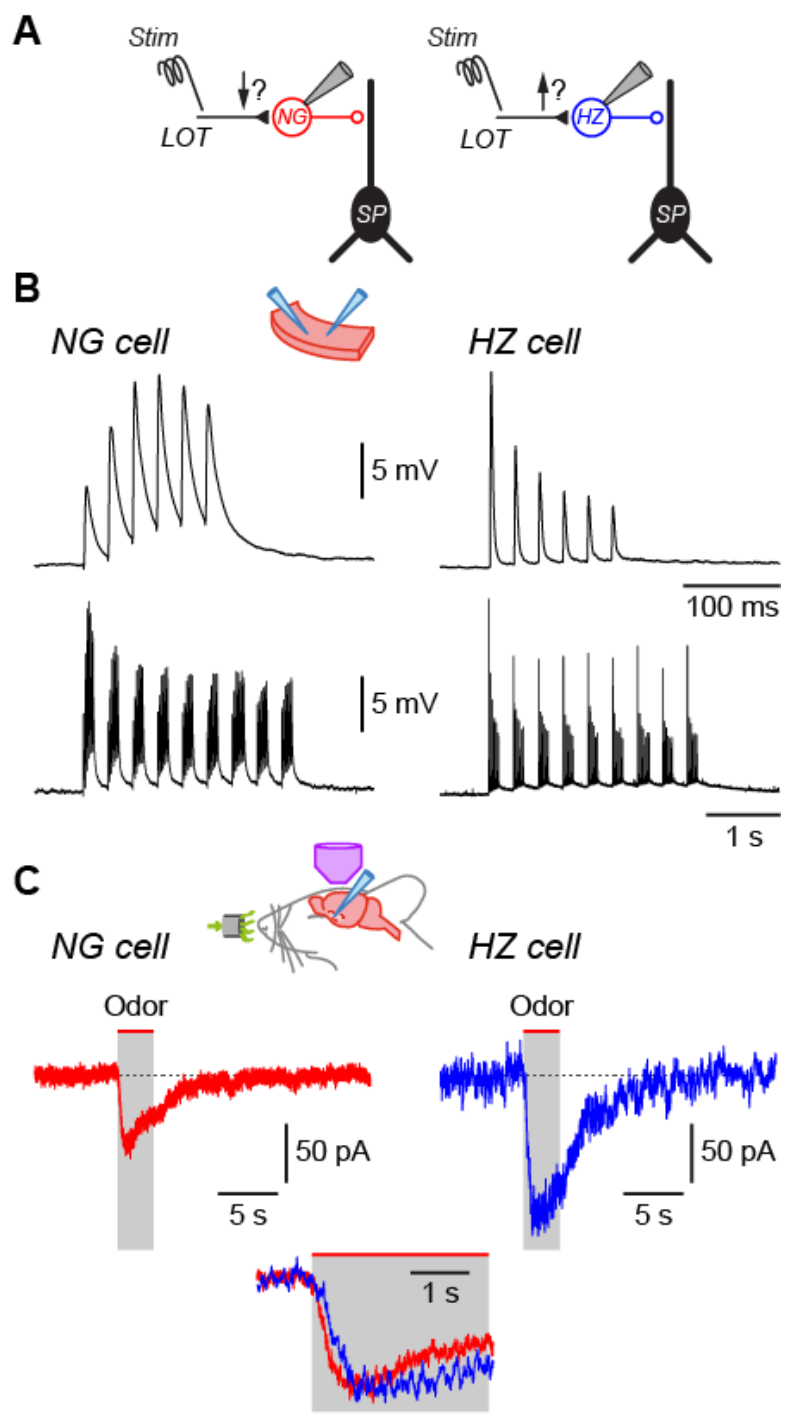

Figure 5. Differences in EPSC kinetics partly account for the different odor responsiveness of $N G$ and $H Z$ cells 
exact opposite of what was required: NG cells facilitated and $\mathrm{HZ}$ cells depressed

246 (Figure 5B, top). We next tried a more realistic model of odor-evoked afferent 247 excitation, i.e. a train of $40 \mathrm{~Hz}$ stimuli repeating at $3 \mathrm{~Hz}$ (the approximate respiration 248 frequency in mice; Poo and Isaacson, 2009). This stimulus produced a modestly 249 depressing envelope of EPSPs in both NG and HZ cells (Figure 5B, bottom). Thus, the 250 short-term dynamics of the LOT afferents could explain the declining response to odors 251 in NG cells, but not the facilitating response in HZ cells.

To further explore this question, we returned to in vivo recordings but now used 253 whole-cell voltage clamp to isolate odor-evoked EPSCs at a holding potential 254 of $-70 \mathrm{mV}$ (Figure 5C). Similar to the result for EPSPs (previous section), the time 255 between odor onset and EPSC peak was about 2-fold faster in NG cells than in HZ cells 256 (NG: $0.72 \pm 0.09 \mathrm{~s}, n=30$ cell-odor pairs; HZ: $1.24 \pm 0.12 \mathrm{~s}, n=21$ cell-odor pairs; $p=$ 257 0.0014, unpaired t-test; Figure 5C inset, bottom). Thus, given that the membrane time 258 constant is fast ( $\sim 4 \mathrm{~ms})$ and not significantly different between NG and HZ cells 259 (Suzuki and Bekkers, 2010a), the slower EPSC risetime in HZ cells is consistent with 260 the slower-rising EPSP (Figure 4A) and the delayed onset of odor-evoked spiking in 261 HZ cells (Figure 3).

262 In summary, despite the in vitro finding that $\mathrm{HZ}$ cells do not receive facilitating 263 EPSPs from the LOT (Figure 5B), both current clamp (Figure 4A) and voltage clamp 264 (Figure 5C) experiments in vivo show that HZ cells do receive slower-rising synaptic 265 inputs than NG cells. Thus, the dynamics of excitatory synaptic inputs at least partially 266 determine the delayed odor responses of $\mathrm{HZ}$ cells, although the origin of these slower 267 dynamics remains unclear (see Discussion). 
bioRxiv preprint doi: https://doi.org/10.1101/2021.09.19.460974; this version posted September $19,2021$. The copyright holder for this

preprint (which was not certified by peer review) is the author/funder, who has granted bioRxiv a license to display the preprint in perpetuity. It is made available under aCC-BY 4.0 International license.

Suzuki et al - p 17

Synaptic inhibition also contributes to the odor responses of $\mathrm{NG}$ and $\mathrm{HZ}$ cells

Although we have so far focused on excitatory synaptic inputs, a likely

271 contribution of inhibitory inputs cannot be excluded. NG and HZ cells may engage in

272 mutual inhibition, thereby modifying the odor-evoked excitation both receive from the

273 LOT. We addressed this possibility by making in vivo whole-cell voltage clamp

274 recordings to look for odor-evoked IPSCs in isolation at a holding potential of $+10 \mathrm{mV}$

275 (Poo and Isaacson, 2009). Such IPSCs were, indeed, present in both HZ and NG cells

276 (Figure 6A). Their properties were not significantly different between the two cell

277 types (mean amplitude: $50.3 \pm 4.3 \mathrm{pA} v s 49.9 \pm 11.0 \mathrm{pA}$; time to peak: $0.58 \pm 0.12 \mathrm{~s} v s$

$2780.35 \pm 0.05 \mathrm{~s}$; data for NG and HZ cells, respectively; all $p>0.1, n=14$ and 5 cell-odor

279 pairs, respectively). Current clamp experiments confirmed that odor-evoked IPSPs

A

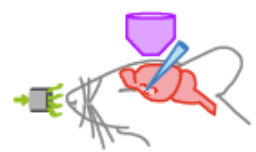

NG cell $\quad H Z$ cell

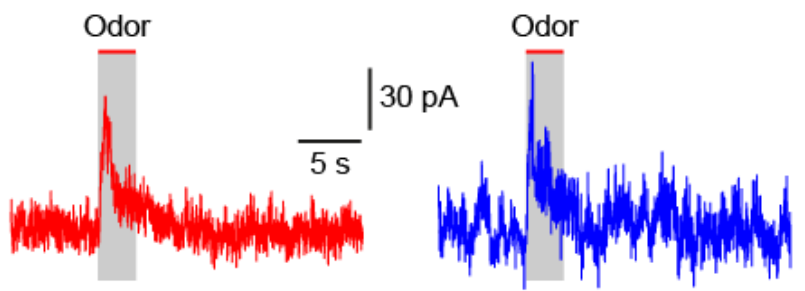

B
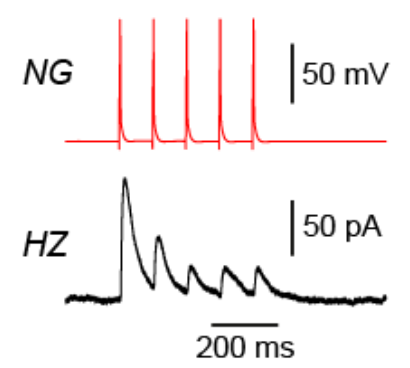

C

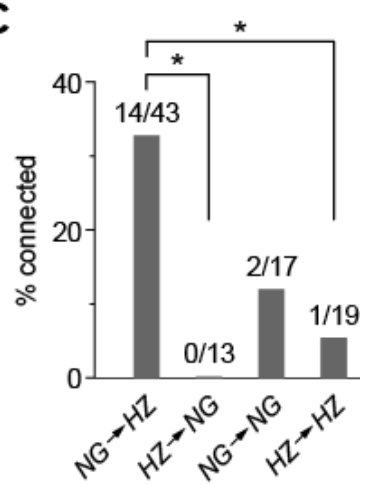

Figure 6. $\mathrm{NG}$ and $\mathrm{HZ}$ cells receive odor-evoked feedforward inhibition, predominantly from other NG cells. 
could also be observed in HZ cells when they were depolarized by somatic current injection (Figure 6 - Figure Supplement 1).

What might be the origin of these inhibitory inputs? We addressed this question by making pair recordings in slices. These experiments revealed that $\mathrm{NG} \rightarrow \mathrm{HZ}$ cell connections were frequent and strong (Figure 6B, C; 14/43 = 32.6\% connectivity; mean connection conductance $0.87 \pm 0.41 \mathrm{nS}$, range $0.10-5.86 \mathrm{nS}, n=14$ pairs) whereas the reverse connection was never seen $(0 / 13=0 \%$; significantly different, $p=0.02$, Chi287 square $2 \times 2$ contingency test). Synaptic connections were also comparatively rare 288 between NG cells and between HZ cells (11.8\% and 5.3\% respectively; Figure 6C). 289 Thus, odor-evoked synaptic inhibition of both NG and HZ cells is mostly likely 290 provided by NG cells after they are excited by input from the LOT.

\section{Feedforward inhibition alters the synaptic responsiveness of SP cells}

Lastly, we explored the functional consequences of $\mathrm{HZ}$ and NG cell inhibition for one of their major targets, layer 2 superficial pyramidal (SP) cells. Because it is difficult to disambiguate these two types of feedforward inhibition in vivo, we conducted the experiments in slices.

We began by eliciting in vivo-like IPSPs in SP cells. Extracellular stimuli were applied to layer $1 \mathrm{a}$ in patterns obtained from the in vivo odor-evoked firing patterns of NG and HZ cells (Figure 7A, red traces), and averaged postsynaptic IPSPs were

300 recorded in SP cells while pharmacologically blocking ionotropic glutamate receptors

301 (Figure 7A, black traces; average of $n=44$ or 51 single traces for 13 or 3 different NG 302 or HZ cell stimulus patterns, respectively, while recording from 6 different SP cells).

303 Two further manipulations were done to make the recordings more in vivo-like. 304 First, NG stimulus recordings were made distant $(>400 \mu \mathrm{m})$ from the LOT to avoid 
bioRxiv preprint doi: https://doi.org/10.1101/2021.09.19.460974; this version posted September 19, 2021. The copyright holder for this

preprint (which was not certified by peer review) is the author/funder, who has granted bioRxiv a license to display the preprint in perpetuity. It is made available under aCC-BY 4.0 International license.

Suzuki et al - p 19

305 stimulating HZ cell axons, which are clustered around the LOT (Suzuki and Bekkers,

306 2010a). On the other hand, HZ stimulus recordings were made near the LOT, where a

307 mixture of $\mathrm{HZ}$ and NG cell axons were likely excited. Second, the stimulus patterns

308 were linearly warped so that the respiration trace recorded for each stimulus pattern

309 matched a reference respiration trace (shown in gray, Figure 7A, bottom). This was

A

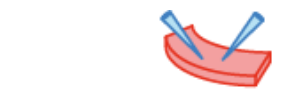

NG cell stim

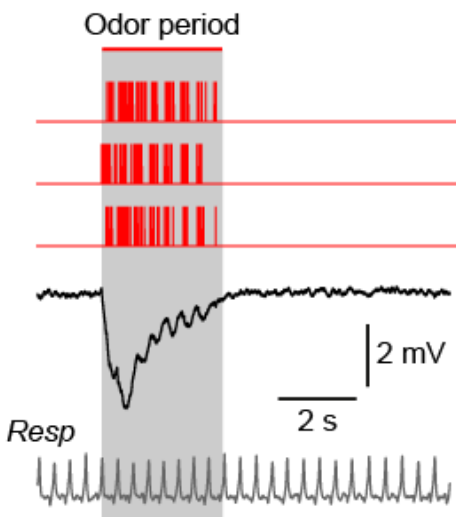

HZ cell stim

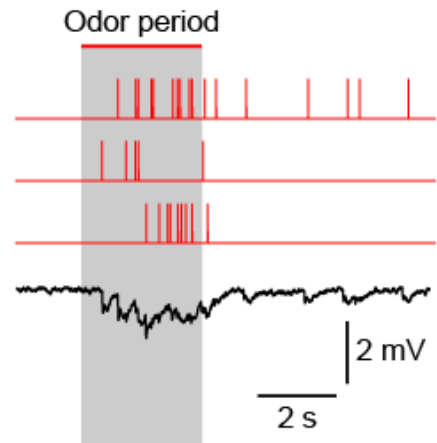

Resp

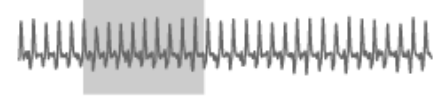

B
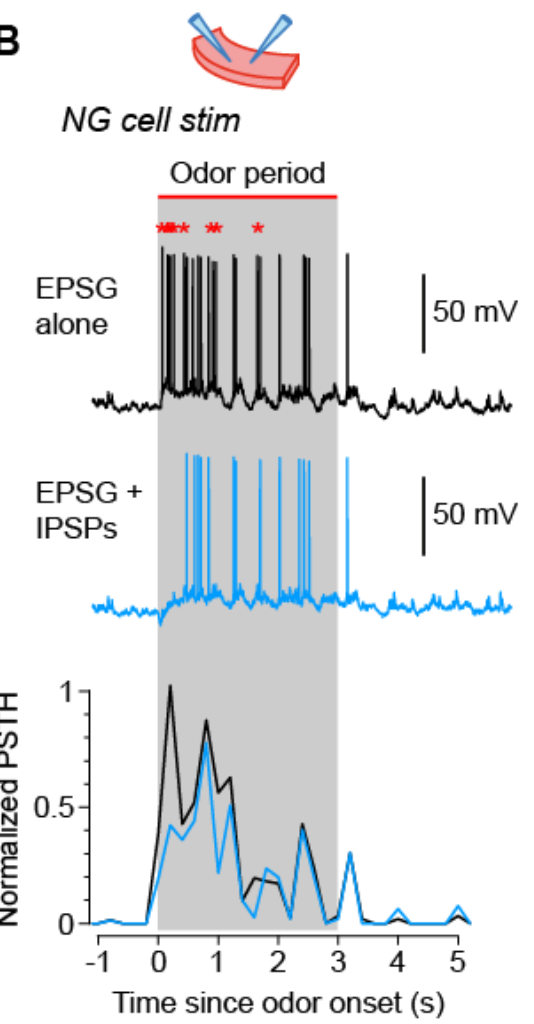

HZ cell stim

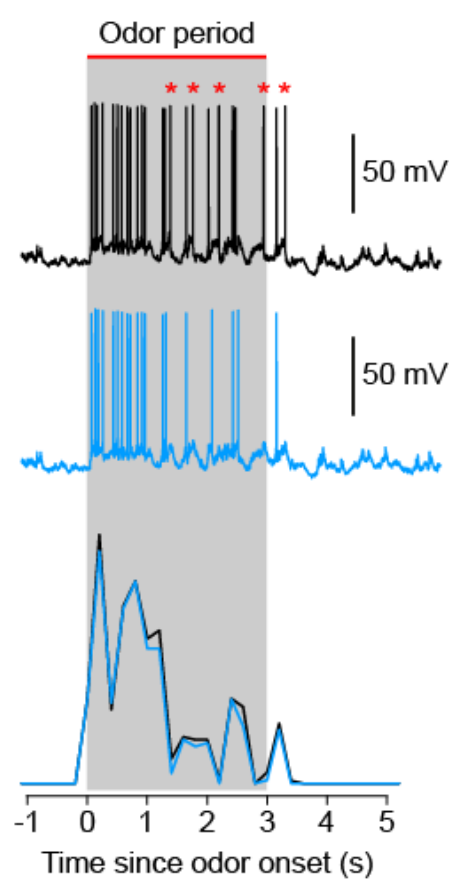

Figure 7. NG and $\mathrm{HZ}$ cells produce different patterns of synaptic inhibition in postsynaptic SP cells. 
310 done to preserve any respiration-synchronized structure in the stimulus patterns when

311 averaging across stimuli. Such synchronization is apparent in the respiration-locked

312 oscillations in the averaged IPSPs (Figure 7A, black traces). These results show that

313 NG cells generate a large, rapid IPSP in SP cells, whereas HZ cells generate a smaller

314 and more diffuse IPSP that persists beyond the end of odor application.

315 In a final series of experiments we examined the effect of these two types of 316 synaptic inhibition on spiking patterns in postsynaptic SP cells. The method described 317 in the previous paragraph was employed, except that a dynamic clamp was used to 318 replay into the SP cell an odor-evoked excitatory postsynaptic conductance (EPSG) that 319 had previously been recorded from an SP cell in vivo. Again, the EPSG and all stimulus 320 patterns were linearly warped to match their respiration traces. When injecting the 321 EPSG alone, an in vivo-like train of action potentials was evoked in the SP cell (Figure $3227 \mathrm{~B}$, black traces). When patterned extracellular stimuli were applied at the same time, 323 eliciting IPSPs, fewer action potentials were evoked in the SP cell by the EPSG (Figure 324 7B, blue traces; spikes that dropped out are indicated by asterisks above the black 325 traces). These effects were quantified by calculating normalized PSTHs for action 326 potentials in the SP cell (Figure 7B, bottom; averages from $n=7$ [with NG stimulation] 327 or $n=4$ [with HZ stimulation] SP cells). The results confirm that NG cells strongly 328 suppress early odor-evoked firing in SP cells ( $p<0.001$, KS test), whereas HZ cells 329 tend to have a weaker, delayed effect (here, not significant; $p=0.81, \mathrm{KS}$ test).

Discussion

In this paper we used whole-cell patch clamping and 2-photon $\mathrm{Ca}^{2+}$ imaging in 333 vivo to characterize the odor responses of two types of GABAergic interneurons that 334 provide feedforward inhibition in the input layer (layer 1a) of the anterior piriform 
cortex. We find that both NG cells and HZ cells are broadly excited by different odors,

336 but the time to reach peak excitation is much slower in $\mathrm{HZ}$ cells than in NG cells. This

337 difference can be explained by a 2-fold slower time to peak of the odor-evoked

338 compound EPSC in HZ cells compared to NG cells. Synaptic inhibition of HZ cells by

339 NG cells may also help to suppress early firing of $\mathrm{HZ}$ cells. In addition, these two cell

340 types differ in their oscillatory response to odors, with NG cells showing larger-

341 amplitude respiration-coupled EPSPs during odor sampling. Lastly, we show that NG

342 and $\mathrm{HZ}$ cells have distinctive effects on the excitability of downstream pyramidal

343 neurons: NG cells generate powerful inhibition immediately after odor onset, whereas

$344 \mathrm{HZ}$ cells exert more diffuse and prolonged inhibition. Our findings reveal a remarkable

345 richness in inhibitory control at the very first stage of cortical odor processing, and add

346 to a growing understanding of the role of afferent-driven feedforward inhibition in 347 cortical processing more broadly (Khubieh et al., 2016; Fan et al., 2020; Anastasiades 348 et al., 2021).

\section{Use of anesthesia}

Two-photon targeted patch clamping and $\mathrm{Ca}^{2+}$ imaging as implemented in this

352 study require direct access to the surface of the PCx (Margrie et al., 2003; Tantirigama 353 et al., 2017). Although similar experiments can be done during wakefulness and semi354 paralysis of mice (Pashkovski et al., 2020), our animal ethics protocols required us to 355 conduct all surgery and experiments under general anesthesia. We used urethane at the 356 minimum concentration empirically determined to be effective in providing stable 357 anesthesia with complete abolition of reflexes $(0.7 \mathrm{~g} / \mathrm{kg}$ s.c. $)$. Urethane has been widely 358 used in previous in vivo studies of the PCx (e.g. Barnes et al., 2008; Poo and Isaacson, 359 2009; Poo and Isaacson, 2011; Wesson et al., 2011; Chapuis and Wilson, 2012; Sturgill 
bioRxiv preprint doi: https://doi.org/10.1101/2021.09.19.460974; this version posted September 19, 2021. The copyright holder for this preprint (which was not certified by peer review) is the author/funder, who has granted bioRxiv a license to display the preprint in perpetuity. It is made available under aCC-BY 4.0 International license.

Suzuki et al - p 22

360 and Isaacson, 2015), and we have confirmed that urethane at this concentration has no

361 effect on electrical activity in the PCx compared with mice anesthetised with

362 fentanyl/medetomidine (which induces a more awake-like brain state; Figure 3 - Figure

363 Supplement 2; Constantinople and Bruno, 2011; Tantirigama et al., 2017). We avoided

364 using ketamine/xylazine anesthesia which has been reported to alter PCx activity

365 through its blockade of NMDA receptors (Fontanini and Bower, 2005; Tantirigama et

366 al., 2017; Bolding et al., 2020). Despite these considerations, however, it remains

367 possible that our findings are affected by urethane and further study is warranted.

Comparison with previous findings

Most previous work has used electrical stimulation in slices to study feedforward

371 inhibition in the PCx (Luna and Schoppa, 2008; Stokes and Isaacson, 2010; Suzuki and

372 Bekkers, 2010a; Suzuki and Bekkers, 2012; Sheridan et al., 2014; Stokes et al., 2014;

373 Large et al., 2016a; Large et al., 2016b). Only two reports, to our knowledge, have

374 explicitly examined this feedforward circuit using odor stimulation in vivo. Poo and

375 Isaacson (2009) made blind whole-cell recordings from neurons in layer 1, while

376 Bolding and Franks (2018) made unit recordings from optogenetically identified

377 GABAergic neurons in layer 1. However, neither study distinguished interneuron 378 subtypes.

379 We found broad tuning of odor-evoked EPSPs in NG and HZ cells, consistent 380 with previous findings (Poo and Isaacson, 2009; odor-averaged index, $0.50 \pm 0.04 c f$ 3810.75 and 0.60 for NG and HZ cells, respectively, found here). Interestingly, broad odor382 tuning has also been reported for some (Zhan and Luo, 2010; Poo and Isaacson, 2011; 383 Bolding and Franks, 2017) but not all (Sturgill and Isaacson, 2015) classes of feedback 384 inhibitory neurons located in deeper layers of the PCx. It is likely that this diversity in 
stimulus tuning reflects the number and variety of functional inputs from upstream

386 neurons. Indeed, it has been shown that Layer 1 interneurons receive a higher

387 convergence of afferent input from the olfactory bulb than do principal neurons (Poo

388 and Isaacson, 2009; Miyamichi et al., 2011). Future work could repeat these

389 experiments while distinguishing NG and HZ cells. Differences might arise because

390 HZ cells, unlike NG cells, are clustered around the LOT where they may encounter a

391 higher density of afferents (Suzuki and Bekkers, 2010a).

392 We often observed oscillations in subthreshold $V_{m}$ that were phase-locked to 393 respiration, consistent with previous reports that such oscillations are ubiquitous in the 394 olfactory system (Fontanini and Bower, 2006; Kay et al., 2009; Poo and Isaacson, 2009; 395 Wilson, 2010; Oswald and Urban, 2012; Kay, 2014; Jiang et al., 2017). Our novel 396 finding was that respiratory oscillations in $V_{m}$ often increased in amplitude during odor 397 sampling, but only in NG cells. These odor-dependent oscillations were functionally 398 relevant because they generated respiratory-patterned IPSPs in target neurons (Figure $3997 \mathrm{~A}$ ) and provided rhythmic inhibition of similarly patterned EPSPs (Figure 7B; see also 400 Poo and Isaacson, 2009). This difference between NG and HZ cells suggests that NG 401 cells provide fast, phase-critical feedforward inhibition whereas HZ cells provide a 402 slower, tonic form of inhibition. Interestingly, Bolding and Franks (2018) reported only 403 the latter kind of feedforward inhibition in multi-unit recordings from awake mice.

\section{Difference in odor-evoked EPSP kinetics}

Our main finding is that odor-evoked firing in $\mathrm{HZ}$ cells has a delayed onset, 407 contrasting with the rapid onset in NG cells. We showed that this effect can be at least 408 partly explained by the slower time-to-peak of the odor-evoked compound EPSC in HZ 409 cells (Figure 5C). Surprisingly, however, these kinetic differences cannot be explained 
by the properties of short-term synaptic plasticity at LOT synapses, assayed in slices

411 (Figure 5B). What might be alternative explanations?

413 types of projection neurons in the olfactory bulb, mitral and tufted cells. Mitral cells

414 have been reported to respond about 2-fold more slowly to odor stimulation than tufted 415 cells (Fukunaga et al., 2012; Igarashi et al., 2012) because of differences in synaptic 416 inhibition in the bulb (Fukunaga et al., 2012; Geramita and Urban, 2017). It is possible 417 that mitral and tufted cell axons preferentially target HZ and NG cells, respectively. 418 Thus, the delayed odor response of $\mathrm{HZ}$ cells may originate in the olfactory bulb rather 419 than at synaptic terminals in the PCx. This could be tested anatomically, or by 420 recording from $\mathrm{HZ}$ or NG cells in vivo while preferentially exciting mitral or tufted 421 cells (Fukunaga et al., 2012; Geramita and Urban, 2017).

A second possible explanation is that $\mathrm{HZ}$ cells may receive delayed bulbar input 423 via an intermediary, such as the anterior olfactory nucleus (Haberly and Price, 1978; 424 McGinley and Westbrook, 2011; Kay and Brunjes, 2014). This could again be tested anatomically or by silencing the anterior olfactory nucleus during odor application.

A third possibility is that lateral inhibition from NG cells counteracts early excitation in $\mathrm{HZ}$ cells, delaying depolarization. In support of this idea, NG cells 428 profusely innervate $\mathrm{HZ}$ cells (Figure 6C) and an odor-evoked hyperpolarization with 429 the right time course can be observed in HZ cells (Figure 6 - Figure Supplement 1). 430 On the other hand, NG cells also receive odor-evoked synaptic inhibition, presumably 431 from other NG cells (Figure 6A), yet do not exhibit delayed odor responses like HZ 432 cells. It is possible that inhibition from NG cells is larger in $\mathrm{HZ}$ cells but it was not 433 apparent here because the number of experiments was relatively small. 
Suzuki et al - p 25

\section{Functional significance of feedforward inhibition in the PCx}

Feedforward inhibition is generally recognized as an input-tracking mechanism which, in the hippocampus and neocortex, can synchronize spike timing (Pouille and Scanziani, 2001; Gabernet et al., 2005) and modulate gain through input normalization (Pouille et al., 2009). The PCx is unusual in that it receives its feedforward inhibitory input onto the distal apical dendrites of principal cells, rather than onto perisomatic regions as in other cortices (Lourenco et al., 2020). What are the consequences of this atypical architecture for the role of feedforward inhibition in the $\mathrm{PCx}$ ?

One slice study has shown that feedforward inhibition works together with feedback inhibition to provide spatially and temporally modulated inhibition during bursts of olfactory input (Stokes and Isaacson, 2010). Intriguingly, the shift in inhibition reported by Stokes and Isaacson (2010) is in the opposite direction to that found in other brain regions (Pouille and Scanziani, 2004; Silberberg and Markram, 2007). These results suggest that feedforward inhibition in the PCx is functionally important but has unusual features.

More recently, an in vivo unit recording study in awake mice showed that odorevoked spiking in feedforward inhibitory neurons in the PCx increases only slowly and weakly after inhalation, suggesting that these neurons provide tonic inhibition and do not play a major role in sculpting odor-evoked responses (Bolding and Franks, 2018). Modeling confirmed that feedforward inhibition provides modest subtractive normalization in the $\mathrm{PCx}$, in contrast to the divisive normalization it provides in other cortical regions (Stern et al., 2018). An intuitive explanation is that the PCx is a comparatively 'slow' processing device. Odor stimuli tend to be slow, and the PCx uses a temporal or rate-based code that is more susceptible to 'recurrent normalization' provided by feedback inhibition (Sturgill and Isaacson, 2015; Bolding and Franks, 
bioRxiv preprint doi: https://doi.org/10.1101/2021.09.19.460974; this version posted September 19, 2021. The copyright holder for this preprint (which was not certified by peer review) is the author/funder, who has granted bioRxiv a license to display the preprint in perpetuity. It is made available under aCC-BY 4.0 International license.

Suzuki et al - p 26

460

461

462

463

464

465

466

467

468

469

470

471

472

473

474

475

476

477

478

482

483

2018; Stern et al., 2018; Bolding et al., 2020; Pashkovski et al., 2020). Hence, the evidence of Bolding and colleagues suggests that feedforward inhibition plays a minor role in odor processing under the conditions of their experiments.

The results of Bolding and colleagues seem at variance with our finding that many layer 1a interneurons, especially NG cells, respond vigorously to odors. The discrepancy may lie in the different recording conditions, e.g. whole-cell $v s$ unit recordings, placement of the electrodes (close to or far from the LOT), or our use of anesthesia. Further work is required. However, if feedforward inhibition in the $\mathrm{PCx}$ is, indeed, weakly engaged in normal olfactory processing, what other functions might it serve?

The key property of feedforward inhibition in the PCx may be its dendritic localization. By inhibiting the distal apical dendrites of layer $2 / 3$ principal cells, NG and $\mathrm{HZ}$ cells have the potential to dampen passive propagation of afferent EPSPs to the soma and to veto dendritic electrogenesis (Larkum et al., 1999; Palmer et al., 2014; Pardi et al., 2020; Anastasiades et al., 2021). Indeed, it has been directly shown in vitro that a single layer 1 interneuron can inhibit $\mathrm{Ca}^{2+}$ signaling in the distal dendrites of $\mathrm{PCx}$ principal cells in a branch-specific fashion (Stokes et al., 2014). Feedforward inhibition might then provide a mechanism for regulating processes that depend on dendritic electrogenesis - including burst-firing (Tseng and Haberly, 1989; Protopapas and Bower, 2001) and spike timing-dependent plasticity (Kanter et al., 1996; Johenning et al., 2009; Cassenaer and Laurent, 2012) - that may only become apparent during experimental paradigms that engage olfactory learning (Wilson and Stevenson, 2006; Ghosh et al., 2015; Shakhawat et al., 2015; Meissner-Bernard et al., 2019). Future work would need to explore this possibility. 
Suzuki et al - p 27

485

\section{Two types of feedforward inhibition}

We have previously shown in slices that layer 1a NG cells and $\mathrm{HZ}$ cells generate slow-rising (2-3 ms) and fast-rising (1 ms) feedforward unitary IPSPs, respectively, in layer 2 principal neurons, leading us to suggest that NG cell-mediated feedforward inhibition is slower and more diffuse than that provided by HZ cells (Suzuki and Bekkers, 2012). In the present report, after taking into account the much slower odorevoked excitatory drive received by $\mathrm{HZ}$ cells, we reach the opposite conclusion. Our results are a reminder that the unitary properties of synapses, measured in vitro, can be less important than the patterns of concerted synaptic activity occurring in vivo.

What might be the value of delivering fast (NG) and slow (HZ) feedforward inhibition? We have shown in a slice simulation (Figure 7) that NG cells can strongly inhibit firing in principal cells immediately after a step application of odor. Although this effect was not observed in the study of Bolding and Franks (2018), there nevertheless appears to be scope for a physiological role for this kind of fast inhibition. For instance, NG cells generate GABA transients that spill out of the synaptic cleft and can activate heterosynaptic $\mathrm{GABA}_{\mathrm{A}}$ and $\mathrm{GABA}_{\mathrm{B}}$ receptors (Karayannis et al., 2010; Overstreet-Wadiche and McBain, 2015). Future work could explore ways in which this 'volume transmission' could enhance computational complexity in the PCx.

The role of HZ cell-mediated feedforward inhibition is more puzzling. Our slice simulation showed that $\mathrm{HZ}$ cells generate a delayed, diffuse response with little effect on principal cell excitability (Figure 7). Trained rodents can discriminate odors within a single sniff (<100 ms; Uchida and Mainen, 2003; Abraham et al., 2004; Rinberg et al., 2006; Resulaj and Rinberg, 2015). What could be the relevance of late-firing HZ cells in this scenario? Two unique features of HZ cells suggest that they are potentially important. First, HZ cells are only found close to the LOT ( $\$ 200 \mu \mathrm{m})$, giving them 
510 privileged inhibitory influence over a spatially restricted subset of principal cells

511 (Suzuki and Bekkers, 2010a; Suzuki and Bekkers, 2012). Second, they are the only

512 class of interneuron in the $\mathrm{PCx}$, and one of few in the cerebral cortex, that are profusely

513 spiny (Haberly, 1983). Given the importance of spines for synaptic plasticity (Engert

514 and Bonhoeffer, 1999; Maletic-Savatic et al., 1999; Toni et al., 1999; Matsuzaki et al.,

515 2004; Tonnesen et al., 2014), HZ cells are poised to receive learning-dependent

516 synaptic excitation, which in turn may allow them to exert adjustable inhibitory control

517 over neurons in their neighborhood.

518 In summary, we have shown that two forms of odor-evoked feedforward 519 inhibition, fast and slow, are expressed in layer 1a of the PCx. Our work reveals a 520 previously unknown multi-functional circuit element in the PCx, and adds to a growing 521 understanding of the role of neurons in layer 1 of the cerebral cortex.

\section{Materials and Methods}

524 All experimental procedures were approved by the Animal Experimentation Ethics 525 Committee of the Australian National University and conform to the Australian Code 526 for the Care and Use of Animals for Scientific Purposes, published by the National 527 Health and Medical Research Council of Australia.

Animals and surgery for 'in vivo' experiments

531 background (Tamamaki et al., 2003). Animals were aged 35-75 days and weighed 17-

$53224 \mathrm{~g}$. For surgery, an animal was sedated with chlorprothixene $(5 \mathrm{mg} / \mathrm{kg}$ i.p. $)$ then 533 injected with urethane $(0.7 \mathrm{~g} / \mathrm{kg}$ s.c. $)$ for general anesthesia plus atropine (0.2$5340.3 \mathrm{mg} / \mathrm{kg}$ s.c.) to reduce secretions. The correct level of anesthesia was confirmed by 
535 observing regular respiration and the complete absence of a pinch reflex; a topup dose

536 of urethane was sometimes required after 5-6 hours. A local anesthetic (prilocaine,

$5370.2 \mathrm{mg} / \mathrm{kg}$ ) was applied topically to incision sites during surgery. Access to the PCx

538 was via the cheek and upper mandible, as previously described (Stettler and Axel, 2009;

539 Tantirigama et al., 2017). Briefly, the following surgical procedure was used (total

540 duration $\sim 2 \mathrm{~h}$ ). After retracting the skin, superficial blood vessels of the cheek were

541 cauterized, then the temporalis muscle was carefully detached and retracted towards its

542 base near the eye, revealing the temporal aspect of the skull. The zygomatic bone and

543 the upper sections of the mandible, including the coronoid and the condyloid processes,

544 were removed, followed by the upper section of the masseter muscle, exposing the

545 basolateral surface of the skull. At this point, the PCx was visible under the translucent

546 skull, identifiable using anatomical landmarks such as the lateral olfactory tract (LOT)

547 and the middle cerebral artery (MCA), which are roughly perpendicular to each other.

548 A metal head post was then glued on top of the skull and the head was stabilized. A

549 craniotomy $\left(\sim 2 \mathrm{~mm}^{2}\right)$ was made with a fine drill (Osada Electric, Nagoya, Japan, or

550 Ram Products Inc, Dayton, NJ) just caudal to the MCA and close to the LOT. This

551 placement of the craniotomy ensured that all recordings were made in the anterior PCx.

552 In many experiments the dura was left intact, but in some the dura was carefully

553 removed using a needle and fine forceps. For the targeted patching a coverglass

554 fragment was glued in place over the craniotomy, leaving a gap at one edge for electrode

555 access. For the calcium imaging a gap was not required, and for 'blind' patch clamping

556 a coverslip was not used. After completion of the surgery a small chamber made from

557 a plastic weighboat and dental cement was constructed around the site. The chamber

558 was filled with phosphate-buffered saline to keep the area hydrated and allow

559 immersion of the microscope objective. For all the above procedures, as well as during 
bioRxiv preprint doi: https://doi.org/10.1101/2021.09.19.460974; this version posted September 19, 2021. The copyright holder for this preprint (which was not certified by peer review) is the author/funder, who has granted bioRxiv a license to display the preprint in perpetuity. It is made available under aCC-BY 4.0 International license.

Suzuki et al - p 30

560

561

562

563

564

565

566

567

568

569

570

571

572

573

574

575

576

577

578

579

580

581

582

583

584

recordings, the animal was placed on an electrically-heated surface at $\sim 37^{\circ} \mathrm{C}$ and was kept hydrated by periodic s.c. injections of normal saline with $2 \%$ dextrose.

\section{Two-photon targeted patch clamping}

GFP-positive interneurons in GAD67-GFP ( $\Delta$ neo) mice were visualized using a 2-photon MOM microscope (Sutter Instrument Company, Novato, CA) with a 40x/0.8 NA water immersion objective (Olympus, Tokyo, Japan) and a Chameleon Ultra Ti:Sapphire laser (Coherent, Santa Clara, CA) tuned to 800-820 nm (Suzuki et al., 2014). Frames (512 x 512 pixels) were acquired simultaneously through a red and green channel at $\sim 5 \mathrm{~Hz}$ under the control of ScanImage (Vidrio Technologies, Ashburn,

VA). Patch pipettes were pulled with a longer taper than usual and had resistances of 5-8 $\mathrm{M} \Omega$ when filled with internal solution comprising (in $\mathrm{mM}$ ) $135 \mathrm{KMeSO}_{4}, 7 \mathrm{NaCl}$, 0.1 EGTA, $2 \mathrm{Na}_{2} \mathrm{ATP}, 2 \mathrm{MgCl}_{2}, 0.3 \mathrm{GTP}, 10 \mathrm{HEPES}$ at $\mathrm{pH}$ 7.2, supplemented with $0.2-0.4 \%$ biocytin $(295-300 \mathrm{mOs} / \mathrm{kg})$. This solution had a $\mathrm{Cl}^{-}$concentration of $11 \mathrm{mM}$ and a measured junction potential of $-7 \mathrm{mV}$. For voltage clamp experiments $\mathrm{CsMeSO}_{4}$ replaced $\mathrm{KMeSO}_{4}$. These solutions also contained Alexa-594 $(20 \mu \mathrm{M})$ for visualizing the electrode in the red channel. Electrical recordings were obtained using a MultiClamp 700B amplifier (Molecular Devices, San Jose, CA). Data were filtered at $10 \mathrm{kHz}$ and sampled at $20-50 \mathrm{kHz}$ using an Instrutech ITC-18 digitizing interface (HEKA, Ludwigshafen, Germany) under the control of Axograph X (Axograph Scientific, Sydney, Australia). The reference electrode was a $\mathrm{Ag} / \mathrm{AgCl}$ wire inserted under the skin. The patch electrode was advanced rapidly to penetrate the dura, then more slowly to approach the selected cell and obtain a gigaseal whole-cell recording in the usual way (Margrie et al., 2002). For current clamp recordings, bridge balance and capacitance neutralization were adjusted and the cell was allowed to remain at its 
resting potential. For voltage clamp recordings, series resistance compensation was not used. Cells were included in the dataset if they had a mean resting potential more hyperpolarized than $-50 \mathrm{mV}$ and were stable enough to allow the recording of responses to at least 5 odors. In addition, cells had to be unambiguously identified as either NG or $\mathrm{HZ}$ cells according to the criteria given in the Results. At the end of the recording an image stack of the cell was acquired in both the red and green channels.

\section{Blind 'in vivo' patch clamping}

This method was used to measure the EPSGs used in the in vitro simulation in

594 Figure 7B. The dura was removed but a coverslip was not used. Patch electrodes were prepared and filled as for targeted patch clamping, then an electrode was positioned at the surface of the anterior PCx using a dissection microscope. The micromanipulator (MP-285, Sutter Instrument Company, Novato, CA) was zeroed at the surface, then the 598 electrode was advanced rapidly to the search depth $(150-280 \mu \mathrm{m}$, corresponding to 599 layer 2) while applying high pressure $(25 \mathrm{kPa})$, after which the pressure was reduced $600(4-8 \mathrm{kPa})$ and a whole-cell recording obtained using standard techniques (Margrie et 601 al., 2002; Poo and Isaacson, 2009). Data were acquired as described above. EPSGs 602 were calculated from EPSCs recorded under voltage clamp at a holding potential 603 of $-70 \mathrm{mV}$, close to the chloride reversal potential for these solutions. Layer 2 principal 604 neurons (semilunar [SL] and superficial pyramidal [SP] cells) were identified by their 605 intrinsic electrical properties (Suzuki and Bekkers, 2006) and by the recording depth 606 (SL: $150-200 \mu \mathrm{m}$; SP: 200-280 $\mu \mathrm{m}$ ). Cell identity was also confirmed by fixing the 607 brain at the end of the experiment and recovering the morphology of the recorded 608 neuron as previously described (Suzuki et al., 2014). 
bioRxiv preprint doi: https://doi.org/10.1101/2021.09.19.460974; this version posted September 19, 2021. The copyright holder for this preprint (which was not certified by peer review) is the author/funder, who has granted bioRxiv a license to display the preprint in perpetuity. It is made available under aCC-BY 4.0 International license.

Suzuki et al - p 32

610

611

612 Sunnyvale, CA), which was prepared and injected as previously described (Tischbirek

613 et al., 2015). Briefly, the dura was removed and dye (1 mM) was pressure-injected into

614 the PCx at a depth of $\sim 200 \mu \mathrm{m}$ using a glass pipette (tip diameter $\sim 10 \mu \mathrm{m}$ ). A coverslip

615 was glued over the PCx and imaging commenced $>1$ hour after injection. Imaging

616 frames were acquired at $30 \mathrm{~Hz}$ using a custom-modified B-scope 2-photon microscope

617 (Thorlabs, Newton, NJ) with a 16x/0.8 NA water immersion objective (Nikon, Tokyo,

618 Japan), resonance-galvanometer scanners and a Chameleon Ultra Ti:Sapphire laser

619 (Coherent, Santa Clara, CA) tuned to $800-820 \mathrm{~nm}$. Cells were included in the dataset

620 if they unambigously satisfied the fluorescence and soma morphology criteria given in

621 Results, and if they exhibited clear odor responses according to the criteria under Data

622 analysis, below.

\section{Odor presentation}

A custom-built flow-dilution olfactometer was used to deliver up to 15 odors which were diluted to $10 \%$ of their saturated vapor pressure in charcoal-filtered medical air (flow rate $1 \mathrm{~L} / \mathrm{min}$; Bozza et al., 2004). The odors used in this study were: ethanol, 1-pentanol, 1-heptanal, limonene, eugenol, 2-heptanone, acetophenone, butyric acid, benzaldehyde, anisole, lavender oil (Sigma-Aldrich, St Louis, MO), ethyl-n-butyrate, propionic acid (VWR, Poole, United Kingdom), amyl acetate and isoamyl acetate (MP Biomedicals, Sydney, Australia). Odors were presented for $3 \mathrm{~s}$ at $60 \mathrm{~s}$ intervals. Control experiments used a miniPID photo-ionization device (Aurora Scientific, Aurora, Canada) to confirm that odors were presented in a step-like manner $(20-80 \%$ risetime in $46 \pm 2 \mathrm{~ms}, n=9$ odors; Figure 3 - Figure Supplement 1). However, there 
bioRxiv preprint doi: https://doi.org/10.1101/2021.09.19.460974; this version posted September 19, 2021. The copyright holder for this preprint (which was not certified by peer review) is the author/funder, who has granted bioRxiv a license to display the preprint in perpetuity. It is made available under aCC-BY 4.0 International license.

Suzuki et al - p 33

635 was a consistent delay of $242 \pm 6 \mathrm{~ms}(n=9)$ between the switching time of the final

636 valve and the arrival of the odorant at the detector inlet (Figure 3 - Figure Supplement

637 1). All odor arrival times in the paper have been corrected for this delay. The mouse

638 was freely breathing and its respiration was recorded using a piezoelectric strap (Kent

639 Scientific, Torrington, CT) around the abdomen. Control experiments confirmed that

640 the onset of inhalation coincided with the start of the downward step visible in some

641 respiration traces (e.g. Figure 2, Figure 3 - Figure Supplement 2) and the beginning of

642 exhalation corresponded to the peak of the upward spike. Because the upward spike

643 was a more reliable feature, we estimated inhalation onset by reference to the

644 exhalation. In a subset of experiments in which both features were clear, we measured

645 the mean latency from the peak of the exhalation spike to the start of the following

646 inhalation $(239 \pm 8 \mathrm{~ms}$; mean time between exhalation spikes, $365 \pm 12 \mathrm{~ms} ; n=10$

647 mice). Hence, expressed as a fraction of a respiration cycle, inhalation onset occurred

648 at $0.654 \pm 0.007$ after the exhalation spike; this was used to estimate the time of onset

649 of inhalation for all experiments. Odor stimulus onset was defined as the time of the

650 first estimated onset of inhalation that occurred following the corrected odor arrival

651 time. To avoid habituation, each odor was presented only once. Cross-habituation

652 between different odors was not observed.

653

654 Slice experiments

655 Coronal slices $(300 \mu \mathrm{m}$ thick) were obtained from the anterior PCx of GAD67-

656 GFP ( $\Delta$ neo) mice aged 20-30 days, as previously described (Suzuki and Bekkers, 2006;

657 Suzuki and Bekkers, 2012). Briefly, slices were prepared on a tissue slicer (Campden

658 Instruments, Loughborough, United Kingdom) in ice-cold high-divalent cutting

659 solution comprising (in $\mathrm{mM}$ ) $125 \mathrm{NaCl}, 3 \mathrm{KCl}, 0.5 \mathrm{CaCl}_{2}, 6 \mathrm{MgCl}_{2}, 25 \mathrm{NaHCO}_{3}, 1.25$ 
bioRxiv preprint doi: https://doi.org/10.1101/2021.09.19.460974; this version posted September 19, 2021. The copyright holder for this preprint (which was not certified by peer review) is the author/funder, who has granted bioRxiv a license to display the preprint in perpetuity. It is made available under aCC-BY 4.0 International license.

Suzuki et al - p 34

$660 \mathrm{NaH}_{2} \mathrm{PO}_{4}, 2$ ascorbate, 3 pyruvate and 10 glucose (osmolarity $305 \mathrm{mOs} / \mathrm{kg}$ ), bubbled

661 with $5 \% \mathrm{CO}_{2} / 95 \% \mathrm{O}_{2}$ (carbogen). The slices were incubated for $40 \mathrm{~min}$ at $34{ }^{\circ} \mathrm{C}$ in

662 carbogen-bubbled artificial cerebrospinal fluid (ACSF; composition below) then were

663 held at room temperature until required.

664 Whole-cell patch-clamp recordings were made from visually identified GFP-

665 positive interneurons using an Olympus BX51WI microscope equipped with infrared

666 differential interference contrast and wide-field fluorescence, as described previously

667 (Suzuki and Bekkers, 2012). Slices were superfused with warmed ACSF containing

668 (in $\mathrm{mM}$ ) $125 \mathrm{NaCl}, 3 \mathrm{KCl}, 2 \mathrm{CaCl}_{2}, 1 \mathrm{MgCl}_{2}, 25 \mathrm{NaHCO}_{3}, 1.25 \mathrm{NaH}_{2} \mathrm{PO}_{4}$ and 25

669 glucose $(310 \mathrm{mOs} / \mathrm{kg})$, bubbled with carbogen and maintained at $33 \pm 1^{\circ} \mathrm{C}$. The bath

670 solution usually contained 6,7-dinitroquinoxaline-2,3-dione (DNQX, $10 \mu \mathrm{M}$ ) and D-

671 aminophosphonovaleric acid (D-APV, $50 \mu \mathrm{M}$ ) to block ionotropic glutamate receptors

672 (Tocris, Abingdon, United Kingdom). Patch electrodes had resistances of 4-6 M $\Omega$

673 when filled with $\mathrm{KMeSO}_{4}$ - or $\mathrm{CMeSO}_{4}$-based internal solution (same as used in vivo).

674 Unless stated otherwise, all compounds were obtained from Sigma-Aldrich.

675 Recordings were obtained using the same instrumentation and software as for the

676 in vivo experiments. The stimulating electrode was made from a low-resistance patch

677 electrode $(\sim 1 \mathrm{M} \Omega)$ filled with ACSF and coated with conductive paint. For pair

678 recordings, the pre- and postsynaptic electrodes were filled with $\mathrm{KMeSO}_{4}$ - and

$679 \mathrm{CsMeSO}_{4}$-based internal solutions, respectively, allowing the postsynaptic neuron to

680 be voltage clamped at a holding potential of $+50 \mathrm{mV}$ while the presynaptic neuron was

681 allowed to remain at its resting potential in current clamp mode. Cells were included

682 in the dataset if they had a stable resting potential more hyperpolarized than $-60 \mathrm{mV}$

683 (current clamp) or a stable holding current $<-100 \mathrm{pA}$ when held at $-70 \mathrm{mV}$ (voltage

684 clamp). At the end of the experiment the slice was fixed and processed with an $\mathrm{ABC}$ 
bioRxiv preprint doi: https://doi.org/10.1101/2021.09.19.460974; this version posted September 19, 2021. The copyright holder for this preprint (which was not certified by peer review) is the author/funder, who has granted bioRxiv a license to display the preprint in perpetuity. It is made available under aCC-BY 4.0 International license.

Suzuki et al - p 35

685 kit (Vector Laboratories, Burlingame, CA), allowing recovery of the morphologies of

686 the recorded neurons.

687

\section{Patterned stimulation and dynamic clamp experiments in slices}

In vivo-like patterns of inhibitory synaptic stimulation in slice experiments

(Figure 7) were adjusted to a common respiration timebase as follows. First, a subset

691 of odor-evoked firing patterns from NG and HZ cells, together with their associated

692 respiration traces, was randomly selected from the full dataset for each cell type. For

693 each subset, one firing/respiration combination was chosen as a reference, and the first

694 upward peak in the reference respiration trace after odor onset was defined as $t_{0}$. Every

695 other odor-evoked firing pattern in that subset was translated in time to align its first

696 respiration peak after odor onset to $t_{0}$. Working backwards and forwards from $t_{0}$, the

697 respiration trace (and associated firing pattern) of each other pattern was linearly

698 warped so the peaks in its respiration trace matched those of the reference respiration

699 trace. These warped stimulus patterns (examples in Figure 7A, red traces) were then

700 used as the trigger to the extracellular stimulator in slice experiments. The same method

701 was used to align the EPSG to the inhibitory stimulation patterns (Figure 7B). In this

702 case the respiration trace for the EPSG was used as the reference timebase.

704 from an SP cell in response to a 3 s-long application of ethyl-n-butyrate. For each

705 neuron the conductance magnitude was adjusted to produce a similar firing rate with

706 the extracellular stimulus switched off, then the stimulator was switched on to record

707 the effect of synaptic inhibition. In order to provide a reference firing rate for

708 normalizing the PSTH (Figure 7B), a fixed conductance stimulus was inserted at the 
bioRxiv preprint doi: https://doi.org/10.1101/2021.09.19.460974; this version posted September 19, 2021. The copyright holder for this preprint (which was not certified by peer review) is the author/funder, who has granted bioRxiv a license to display the preprint in perpetuity. It is made available under aCC-BY 4.0 International license.

Suzuki et al - p 36

709

710

711

712

713

714

715

716

717

end of the EPSG, well past the odor period (not visible in Figure 7B). The dynamic clamp was implemented using Igor Pro (Wavemetrics, Lake Oswego, OR).

\section{Data analysis}

All analysis was done using Igor Pro, Axograph X, Matlab (MathWorks, Natick, MA), or R (running under RStudio, Boston, MA).

Action potential (AP) properties (Figure 1D) were measured as previously described for slice experiments (Suzuki and Bekkers, 2010a). Latency to the first AP was the delay from the beginning of the current step to the first AP at rheobase. AP height was the difference between the peak of the first AP at rheobase and its threshold voltage (defined as the membrane potential $\left[V_{m}\right]$ at which $d V_{m} / d t$ first exceeded $15 \mathrm{~V} / \mathrm{s}$ ). AP halfwidth was the width of the first AP at rheobase measured at half its height. Respiration-correlated oscillations in $V_{m}$ (Figure 2, Figure 2 - Figure Supplement 1, Figure 2 - Figure Supplement 2) were characterized as follows. Respiration traces were band-pass filtered at $1-50 \mathrm{~Hz}$ and normalized to oscillate between 0 and 1 . The time between successive exhalation spikes was used to calculate the mean respiration frequency in three $3 \mathrm{~s}$-long windows $(-6$ to $-3 \mathrm{~s}, 0$ to $3 \mathrm{~s}$, and 16 to $19 \mathrm{~s}$, all with respect to odor onset). The same three windows were used for the analysis of oscillations in $V_{m}$. First, $V_{m}$ was median-filtered to remove APs. Mean peak-to-peak amplitude of the oscillations in $V_{m}$ was found by excising segments of $V_{m}$ between successive exhalation spikes, linearly stretching ('warping') them so they had the same time axis, then averaging together all segments within each of the three analysis windows. Mean peakto-peak amplitude was taken as the difference between the maximum and minimum amplitude of the averaged segment of $V_{m}$. For cross-covariance analysis (Figure $2-$ 
734 replaced by a normalized series of Gaussians representing the upward spikes in the 735 respiration cycle; this was done to eliminate the effect of differences in the amplitude 736 of the recorded respiration trace. The amplitude of the largest positive peak in the 737 covariance was found, as well as the location of this peak expressed as a fraction of the 738 mean time between exhalation spikes for that window.

The odor response indices were found by: (i) calculating the fraction of odors that

740 each cell responded to, then averaging across cells ('cell-averaged index'); and (ii)

741 calculating the fraction of cells each odor activated, then averaging across odors ('odor-

742 averaged index'). Odor responsiveness was determined using a z-score criterion:

743 median-filtered $V_{m}$ segments demarcated by exhalation spikes were excised as above,

744 and the mean $V_{m}$ in each of these segments was calculated for the entire odor trial.

745 These values were converted to a z-score by subtracting the mean and dividing by the 746 standard deviation of the list of mean $V_{m}$ values during the 8 s-long pre-odor baseline 747 period. An odor response was said to occur if this z-score value exceeded 2.5 for any 748 respiration segment during the 3 s-long odor application period (Figure 1 - Figure 749 Supplement 1). Lifetime sparseness was calculated with a modified expression 750 (Pashkovski et al., 2020) that used the peak z-scored response (without thresholding) 751 as the variable. Individual odor-evoked EPSPs (Figure 4A), EPSCs (Figure 5C) and IPSCs 753 (Figure 6A) were notch-filtered at 2-4 Hz, if required, to remove respiration-associated 754 oscillations prior to averaging (see also Figure 4 - Figure Supplement 1). To estimate 755 the latency to peak and halfwidth, each individual EPSC was fitted to the equation $I(t)=$ $756 a\left(1-e^{-t / \tau l}\right)^{2} e^{-t / \tau 2}$, where $a$ is amplitude and $\tau_{1}$ and $\tau_{2}$ are the rising and falling time 757 constants, respectively. The latency and halfwidth were then measured from this fitted 758 curve. 
bioRxiv preprint doi: https://doi.org/10.1101/2021.09.19.460974; this version posted September 19, 2021. The copyright holder for this preprint (which was not certified by peer review) is the author/funder, who has granted bioRxiv a license to display the preprint in perpetuity. It is made available under aCC-BY 4.0 International license.

Suzuki et al - p 38

760 were analyzed by manually drawing regions of interest around the somas of identified 761 neurons in the green channel then measuring mean somatic fluorescence, $F$, in the red 762 channel for each frame. Baseline fluorescence $\left(F_{0}\right)$ for each neuron was defined as the 763 median of the lower $80 \%$ of all values of $F$ measured in all frames acquired prior to 764 odor application. Plots show $\Delta F / F_{0}=\left(F-F_{0}\right) / F_{0}$.

Pair recordings in slices (Figure 6B, C) were analyzed as follows. The peak 766 postsynaptic current was found within a $10 \mathrm{~ms}$-long window starting $2 \mathrm{~ms}$ after the time 767 of the presynaptic AP, then the mean peak amplitude $\left(a_{p k}\right)$ was found by averaging over 768 a $1 \mathrm{~ms}$ long window around the peak and subtracting the averaged baseline over a $76910 \mathrm{~ms}-$ long window ending $2 \mathrm{~ms}$ before the time of the presynaptic AP. The same 770 measurement procedure was then repeated for 200 randomly-chosen times during the 771500 ms-long baseline period preceding the time of the presynaptic AP, and the standard 772 deviation $\left(s_{b}\right)$ of these baseline mean amplitudes was calculated. A synaptic connection $773 \quad$ was identified if $\left|a_{p k}\right|>\left|3 s_{b}\right|$.

\section{Statistics}

All statistical analysis was done using R (Version 3.6.0) running under RStudio.

777 Sample sizes were not predetermined using a statistical test; we established that our 778 sample sizes were sufficient from the size and statistical significance of the results, and 779 our sizes are similar to those commonly used in the field. Data collection and analysis 780 were not blinded or randomized, but analysis was automated whenever possible. 781 Results are presented as mean \pm standard error of the mean (SEM) with associated exact $782 p$ value ( $n=$ number of cells or cell-odor pairs, as indicated). Pairwise comparisons 783 were done using Welch's unpaired 2-tailed t-test (t.test function in R). Multiple paired 
784

comparisons used 1-way ANOVA with Tukey's contrasts (lmer and glht functions in R) with blocking by cell and odor number. Visual inspection of residual plots did not reveal any large deviations from homoscedasticity. Distributions were compared using the Kolmogorov-Smirnov test (ks.test). Significance is indicated on the figures by $n s$ (not significant) or by one or more asterisks, following the usual convention in R.

\section{Competing interests}

None to declare.

\section{Author contributions}

Norimitsu Suzuki, Conceptualization, Data curation, Software, Formal Analysis, Validation, Investigation, Methodology; Malinda L. S. Tantirigama, Conceptualization, Data curation, Software, Formal Analysis, Validation, Investigation, Visualization, Methodology; Helena H.-Y. Huang, Data curation, Validation, Investigation, Methodology; John M. Bekkers, Conceptualization, Resources, Data curation, Software, Formal Analysis, Supervision, Funding acquisition, Validation, Investigation, Visualization, Methodology, Project administration.

\section{Ethics}

Animal experimentation: This work was performed in strict accordance with the guidelines contained in the Australian Code for the Care and Use of Animals for Scientific Purposes, published by the National Health and Medical Research Council of Australia. All experimental procedures were approved by the Animal Experimentation Ethics Committee of the Australian National University (Protocols A2014/11, A2017/27, A2018/52). All surgeries and experiments were performed under 
809 anesthesia with either urethane or fentanyl/medetomidine, with supplementary

810 isoflurane as required, and every effort was made to minimize suffering.

811

812 Author ORCIDs

813 John M. Bekkers https://orcid.org/0000-0001-8619-5512

814 Malinda L. S. Tantirigama https://orcid.org/0000-0003-0791-9389

815

816 Funding

\begin{tabular}{lll} 
Funder & Grant reference number & Author \\
\hline $\begin{array}{l}\text { National Health \& Medical } \\
\text { Research Council of Australia }\end{array}$ & 1009382 & John M Bekkers \\
(NHMRC) & & \\
NHMRC & 1050832 & John M Bekkers \\
\hline
\end{tabular}

817

818 Additional files

819 Figure Supplements.

820 Figure Data. 
Suzuki et al - p 41

\section{References}

Abraham NM, Spors H, Carleton A, Margrie TW, Kuner T, Schaefer AT. 2004. Maintaining accuracy at the expense of speed: stimulus similarity defines odor discrimination time in mice. Neuron 44:865-76. doi: 10.1016/j.neuron.2004.11.017

Altwegg-Boussac T, Chavez M, Mahon S, Charpier S. 2014. Excitability and responsiveness of rat barrel cortex neurons in the presence and absence of spontaneous synaptic activity in vivo. $J$ Physiol 592:3577-3595. doi: 10.1113/jphysiol.2013.270561

Anastasiades PG, Collins DP, Carter AG. 2021. Mediodorsal and ventromedial thalamus engage distinct L1 circuits in the prefrontal cortex. Neuron 109:314330 e4. doi: 10.1016/j.neuron.2020.10.031

Barnes DC, Hofacer RD, Zaman AR, Rennaker RL, Wilson DA. 2008. Olfactory perceptual stability and discrimination. Nat Neurosci 11:1378-80. doi: $10.1038 / \mathrm{nn} .2217$

Beierlein M, Gibson JR, Connors BW. 2003. Two dynamically distinct inhibitory networks in layer 4 of the neocortex. J Neurophysiol 90:2987-3000. doi: 10.1152 jn .00283 .2003

Bekkers JM, Suzuki N. 2013. Neurons and circuits for odor processing in the piriform cortex. Trends Neurosci 36:429-438. doi: 10.1016/j.tins.2013.04.005

Biedenbach MA, Stevens CF. 1969. Synaptic organization of cat olfactory cortex as revealed by intracellular recording. J. Neurophysiol. 32:204-214. doi: 10.1152/jn.1969.32.2.204

Bolding KA, Franks KM. 2017. Complementary codes for odor identity and intensity in olfactory cortex. Elife 6:10.7554/eLife.22630. doi: 10.7554/eLife. 22630

Bolding KA, Franks KM. 2018. Recurrent cortical circuits implement concentrationinvariant odor coding. Science 361:1-12. doi: 10.1126/science.aat6904

Bolding KA, Nagappan S, Han BX, Wang F, Franks KM. 2020. Recurrent circuitry is required to stabilize piriform cortex odor representations across brain states. Elife 9. doi: 10.7554/eLife.53125

Bozza T, McGann JP, Mombaerts P, Wachowiak M. 2004. In vivo imaging of neuronal activity by targeted expression of a genetically encoded probe in the mouse. Neuron 42:9-21. doi: 10.1016/s0896-6273(04)00144-8

Bruno RM, Sakmann B. 2006. Cortex is driven by weak but synchronously active thalamocortical synapses. Science 312:1622-7. doi: 10.1126/science.1124593

Carandini M, Heeger DJ. 2011. Normalization as a canonical neural computation. Nat Rev Neurosci 13:51-62. doi: 10.1038/nrn3136

Cassenaer S, Laurent G. 2012. Conditional modulation of spike-timing-dependent plasticity for olfactory learning. Nature 482:47-52. doi: 10.1038/nature10776

Chapuis J, Wilson DA. 2012. Bidirectional plasticity of cortical pattern recognition and behavioral sensory acuity. Nat Neurosci 15:155-61. doi: 10.1038/nn.2966

Constantinople CM, Bruno RM. 2011. Effects and mechanisms of wakefulness on local cortical networks. Neuron 69:1061-8. doi: 10.1016/j.neuron.2011.02.040

Cruikshank SJ, Lewis TJ, Connors BW. 2007. Synaptic basis for intense thalamocortical activation of feedforward inhibitory cells in neocortex. Nat Neurosci 10:462-8. doi: 10.1038/nn1861

Denève S, Machens CK. 2016. Efficient codes and balanced networks. Nat Neurosci 19:375-82. doi: 10.1038/nn.4243 
Engert F, Bonhoeffer T. 1999. Dendritic spine changes associated with hippocampal long-term synaptic plasticity. Nature 399:66-70. doi: 10.1038/19978

Fan LZ, Kheifets S, Bohm UL, Wu H, Piatkevich KD, Xie ME, Parot V, Ha Y, Evans KE, Boyden ES, Takesian AE, Cohen AE. 2020. All-optical electrophysiology reveals the role of lateral inhibition in sensory processing in cortical layer 1 . Cell 180:521-535 e18. doi: 10.1016/j.cell.2020.01.001

Fontanini A, Bower JM. 2005. Variable coupling between olfactory system activity and respiration in ketamine/xylazine anesthetized rats. J Neurophysiol 93:3573-81. doi: $10.1152 /$ jn.01320.2004

Fontanini A, Bower JM. 2006. Slow-waves in the olfactory system: an olfactory perspective on cortical rhythms. Trends Neurosci 29:429-37. doi: 10.1016/j.tins.2006.06.013

Franks KM, Russo MJ, Sosulski DL, Mulligan AA, Siegelbaum SA, Axel R. 2011. Recurrent circuitry dynamically shapes the activation of piriform cortex. Neuron 72:49-56. doi: 10.1016/j.neuron.2011.08.020

Fu Y, Tucciarone JM, Espinosa JS, Sheng N, Darcy DP, Nicoll RA, Huang ZJ, Stryker MP. 2014. A cortical circuit for gain control by behavioral state. Cell 156:11391152. doi: 10.1016/j.cell.2014.01.050

Fukunaga I, Berning M, Kollo M, Schmaltz A, Schaefer AT. 2012. Two distinct channels of olfactory bulb output. Neuron 75:320-9. doi: 10.1016/j.neuron.2012.05.017

Gabernet L, Jadhav SP, Feldman DE, Carandini M, Scanziani M. 2005. Somatosensory integration controlled by dynamic thalamocortical feed-forward inhibition. Neuron 48:315-27. doi: 10.1016/j.neuron.2005.09.022

Geramita M, Urban NN. 2017. Differences in glomerular-layer-mediated feedforward inhibition onto mitral and tufted cells lead to distinct modes of intensity coding. J Neurosci 37:1428-1438. doi: 10.1523/JNEUROSCI.2245-16.2016

Ghosh S, Reuveni I, Lamprecht R, Barkai E. 2015. Persistent CaMKII activation mediates learning-induced long-lasting enhancement of synaptic inhibition. $J$ Neurosci 35:128-39. doi: 10.1523/JNEUROSCI.2123-14.2015

Gouwens NW, Sorensen SA, Baftizadeh F, Budzillo A, Lee BR, Jarsky T, Alfiler L, Baker K, Barkan E, Berry K, Bertagnolli D, Bickley K, Bomben J, Braun T, Brouner K, Casper T, Crichton K, Daigle TL, Dalley R, de Frates RA, Dee N, Desta T, Lee SD, Dotson N, Egdorf T, Ellingwood L, Enstrom R, Esposito L, Farrell C, Feng D, Fong O, Gala R, Gamlin C, Gary A, Glandon A, Goldy J, Gorham M, Graybuck L, Gu H, Hadley K, Hawrylycz MJ, Henry AM, Hill D, Hupp M, Kebede S, Kim TK, Kim L, Kroll M, Lee C, Link KE, Mallory M, Mann R, Maxwell M, McGraw M, McMillen D, Mukora A, Ng L, Ng L, Ngo K, Nicovich PR, Oldre A, Park D, Peng H, Penn O, Pham T, Pom A, Popovic Z, Potekhina L, Rajanbabu R, Ransford S, Reid D, Rimorin C, Robertson M, Ronellenfitch K, Ruiz A, Sandman D, Smith K, Sulc J, Sunkin SM, Szafer A, Tieu M, Torkelson A, Trinh J, Tung H, Wakeman W, Ward K, Williams G, Zhou Z, Ting JT, Arkhipov A, Sumbul U, Lein ES, Koch C, Yao Z, Tasic B, Berg J, Murphy GJ, Zeng H. 2020. Integrated morphoelectric and transcriptomic classification of cortical GABAergic cells. Cell 183:935-953 e19. doi: 10.1016/j.cell.2020.09.057

Haberly LB. 1973. Unitary analysis of opossum prepyriform cortex. J Neurophysiol 36:762-774. doi: 10.1152/jn.1973.36.4.762 
Suzuki et al - p 43

Haberly LB. 1983. Structure of the piriform cortex of the opossum. I. Description of neuron types with Golgi methods. J Comp Neurol 213:163-187. doi: $10.1002 /$ cne. 902130205

Haberly LB, Price JL. 1978. Association and commissural fiber systems of the olfactory cortex of the rat. II. Systems originating in the olfactory peduncle. J Comp Neurol 181:781-807. doi: 10.1002/cne.901810407

Hara K, Harris RA. 2002. The anesthetic mechanism of urethane: the effects on neurotransmitter-gated ion channels. Anesth Analg 94:313-8. doi: 10.1097/00000539-200202000-00015

Igarashi KM, Ieki N, An M, Yamaguchi Y, Nagayama S, Kobayakawa K, Kobayakawa R, Tanifuji M, Sakano H, Chen WR, Mori K. 2012. Parallel mitral and tufted cell pathways route distinct odor information to different targets in the olfactory cortex. J Neurosci 32:7970-85. doi: 10.1523/JNEUROSCI.0154-12.2012

Isaacson JS, Scanziani M. 2011. How inhibition shapes cortical activity. Neuron 72:231-43. doi: 10.1016/j.neuron.2011.09.027

Jiang H, Schuele S, Rosenow J, Zelano C, Parvizi J, Tao JX, Wu S, Gottfried JA. 2017. Theta oscillations rapidly convey odor-specific content in human piriform cortex. Neuron 94:207-219 e4. doi: 10.1016/j.neuron.2017.03.021

Johenning FW, Beed PS, Trimbuch T, Bendels MH, Winterer J, Schmitz D. 2009. Dendritic compartment and neuronal output mode determine pathway-specific long-term potentiation in the piriform cortex. J Neurosci 29:13649-61. doi: 10.1523/JNEUROSCI.2672-09.2009

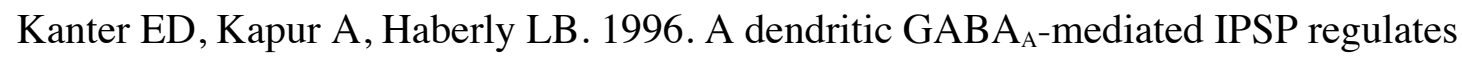
facilitation of NMDA-mediated responses to burst stimulation of afferent fibers in piriform cortex. $J$ Neurosci 16:307-312. doi: 10.1523/JNEUROSCI.16-0100307.1996

Karayannis T, Elfant D, Huerta-Ocampo I, Teki S, Scott RS, Rusakov DA, Jones MV, Capogna M. 2010. Slow GABA transient and receptor desensitization shape synaptic responses evoked by hippocampal neurogliaform cells. J Neurosci 30:9898-909. doi: 10.1523/JNEUROSCI.5883-09.2010

Kawaguchi Y, Kubota Y. 1997. GABAergic cell subtypes and their synaptic connections in rat frontal cortex. Cereb Cortex 7:476-486. doi: 10.1093/cercor/7.6.476

Kay LM. 2014. Circuit oscillations in odor perception and memory. Prog Brain Res 208:223-51. doi: 10.1016/B978-0-444-63350-7.00009-7

Kay LM, Beshel J, Brea J, Martin C, Rojas-Libano D, Kopell N. 2009. Olfactory oscillations: the what, how and what for. Trends Neurosci 32:207-14. doi: 10.1016/j.tins.2008.11.008

Kay RB, Brunjes PC. 2014. Diversity among principal and GABAergic neurons of the anterior olfactory nucleus. Front Cell Neurosci 8:111. doi: 10.3389/fncel.2014.00111

Khubieh A, Ratte S, Lankarany M, Prescott SA. 2016. Regulation of cortical dynamic range by background synaptic noise and feedforward inhibition. Cereb Cortex 26:3357-69. doi: 10.1093/cercor/bhv157

Kullmann DM, Lamsa KP. 2007. Long-term synaptic plasticity in hippocampal interneurons. Nat Rev Neurosci 8:687-99. doi: 10.1038/nrn2207

Large AM, Kunz NA, Mielo SL, Oswald A-MM. 2016a. Inhibition by somatostatin interneurons in olfactory cortex. Front Neural Circ 10:1-17. doi: 10.3389/fncir.2016.00062 
Suzuki et al - p 44

967

968

969

970

971

972

973

974

975

976

977

978

979

980

981

982

983

984

985

986

987

988

989

990

991

992

993

994

995

996

997

998

999

1000

1001

1002

1003

1004

1005

1006

1007

1008

1009

1010

1011

1012

1013

1014
Large AM, Vogler NW, Mielo S, Oswald AM. 2016b. Balanced feedforward inhibition and dominant recurrent inhibition in olfactory cortex. Proc Natl Acad Sci USA 113:2276-81. doi: 10.1073/pnas.1519295113

Larkum ME, Kaiser KMM, Sakmann B. 1999. Calcium electrogenesis in distal apical dendrites of layer 5 pyramidal cells at a critical frequency of back-propagating action potentials. Proc Natl Acad Sci USA 96:14600-14604. doi: 10.1073/pnas.96.25.14600

Lourenco J, Koukouli F, Bacci A. 2020. Synaptic inhibition in the neocortex: Orchestration and computation through canonical circuits and variations on the theme. Cortex 132:258-280. doi: 10.1016/j.cortex.2020.08.015

Luna VM, Schoppa NE. 2008. GABAergic circuits control input-spike coupling in the piriform cortex. J Neurosci 28:8851-9. doi: 10.1523/JNEUROSCI.238508.2008

Maletic-Savatic M, Malinow R, Svoboda K. 1999. Rapid dendritic morphogenesis in CA1 hippocampal dendrites induced by synaptic activity. Science 283:19231927. doi: 10.1126/science.283.5409.1923

Margrie TW, Brecht M, Sakmann B. 2002. In vivo, low-resistance, whole-cell recordings from neurons in the anaesthetized and awake mammalian brain. Pflugers Arch 444:491-8. doi: 10.1007/s00424-002-0831-z

Margrie TW, Meyer AH, Caputi A, Monyer H, Hasan MT, Schaefer AT, Denk W, Brecht M. 2003. Targeted whole-cell recordings in the mammalian brain in vivo. Neuron 39:911-8. doi: 10.1016/j.neuron.2003.08.012

Matsuzaki M, Honkura N, Ellis-Davies GC, Kasai H. 2004. Structural basis of longterm potentiation in single dendritic spines. Nature 429:761-6. doi: 10.1038/nature02617

McGinley MJ, Westbrook GL. 2011. Membrane and synaptic properties of pyramidal neurons in the anterior olfactory nucleus. J Neurophysiol 105:1444-53. doi: 10.1152/jn.00715.2010

Meissner-Bernard C, Dembitskaya Y, Venance L, Fleischmann A. 2019. Encoding of odor fear memories in the mouse olfactory cortex. Curr Biol 29:367-380 e4. doi: 10.1016/j.cub.2018.12.003

Miyamichi K, Amat F, Moussavi F, Wang C, Wickersham I, Wall NR, Taniguchi H, Tasic B, Huang ZJ, He Z, Callaway EM, Horowitz MA, Luo L. 2011. Cortical representations of olfactory input by trans-synaptic tracing. Nature 472:191196. doi: 10.1038/nature09714

Neville KR, Haberly LB 2004. Olfactory cortex. In: Shepherd GM (ed.) The Synaptic Organization of the Brain. 5th ed. New York: Oxford University Press.

Oswald AM, Urban NN. 2012. Interactions between behaviorally relevant rhythms and synaptic plasticity alter coding in the piriform cortex. J Neurosci 32:6092-104. doi: 10.1523/JNEUROSCI.6285-11.2012

Overstreet-Wadiche L, McBain CJ. 2015. Neurogliaform cells in cortical circuits. Nat Rev Neurosci 16:458-68. doi: 10.1038/nrn3969

Palmer LM, Shai AS, Reeve JE, Anderson HL, Paulsen O, Larkum ME. 2014. NMDA spikes enhance action potential generation during sensory input. Nat Neurosci 17:383-90. doi: 10.1038/nn.3646

Pardi MB, Vogenstahl J, Dalmay T, Spano T, Pu DL, Naumann LB, Kretschmer F, Sprekeler H, Letzkus JJ. 2020. A thalamocortical top-down circuit for associative memory. Science 370:844-848. doi: 10.1126/science.abc2399 
1015

1016

1017

1018

1019

1020

1021

1022

1023

1024

1025

1026

1027

1028

1029

1030

1031

1032

1033

1034

1035

1036

1037

1038

1039

1040

1041

1042

1043

1044

1045

1046

1047

1048

1049

1050

1051

1052

1053

1054

1055

1056

1057

1058

1059

1060

1061

1062

1063

Pashkovski SL, Iurilli G, Brann D, Chicharro D, Drummey K, Franks KM, Panzeri S, Datta SR. 2020. Structure and flexibility in cortical representations of odour space. Nature 583:253-258. doi: 10.1038/s41586-020-2451-1

Pi HJ, Hangya B, Kvitsiani D, Sanders JI, Huang ZJ, Kepecs A. 2013. Cortical interneurons that specialize in disinhibitory control. Nature 503:521-4. doi: 10.1038 /nature 12676

Poo C, Isaacson JS. 2009. Odor representations in olfactory cortex: "sparse" coding, global inhibition, and oscillations. Neuron 62:850-61. doi: 10.1016/j.neuron.2009.05.022

Poo C, Isaacson JS. 2011. A major role for intracortical circuits in the strength and tuning of odor-evoked excitation in olfactory cortex. Neuron 72:41-8. doi: 10.1016/j.neuron.2011.08.015

Pouille F, Marin-Burgin A, Adesnik H, Atallah BV, Scanziani M. 2009. Input normalization by global feedforward inhibition expands cortical dynamic range. Nat Neurosci 12:1577-85. doi: 10.1038/nn.2441

Pouille F, Scanziani M. 2001. Enforcement of temporal fidelity in pyramidal cells by somatic feed-forward inhibition. Science 293:1159-1163. doi: $10.1126 /$ science. 1060342

Pouille F, Scanziani M. 2004. Routing of spike series by dynamic circuits in the hippocampus. Nature 429:717-23. doi: 10.1038/nature02615

Protopapas AD, Bower JM. 2001. Spike coding in pyramidal cells of the piriform cortex of rat. J Neurophysiol 86:1504-1510. doi: 10.1152/jn.2001.86.3.1504

Ravia A, Snitz K, Honigstein D, Finkel M, Zirler R, Perl O, Secundo L, Laudamiel C, Harel D, Sobel N. 2020. A measure of smell enables the creation of olfactory metamers. Nature 588:118-123. doi: 10.1038/s41586-020-2891-7

Resulaj A, Rinberg D. 2015. Novel behavioral paradigm reveals lower temporal limits on mouse olfactory decisions. $J$ Neurosci 35:11667-73. doi: 10.1523/JNEUROSCI.4693-14.2015

Rinberg D, Koulakov A, Gelperin A. 2006. Sparse odor coding in awake behaving mice. J Neurosci 26:8857-65. doi: 10.1523/JNEUROSCI.0884-06.2006

Schuman B, Machold RP, Hashikawa Y, Fuzik J, Fishell GJ, Rudy B. 2019. Four unique interneuron populations reside in neocortical Layer 1. J Neurosci 39:125-139. doi: 10.1523/JNEUROSCI.1613-18.2018

Shakhawat AM, Gheidi A, MacIntyre IT, Walsh ML, Harley CW, Yuan Q. 2015. Arcexpressing neuronal ensembles supporting pattern separation require adrenergic activity in anterior piriform cortex: An exploration of neural constraints on learning. J Neurosci 35:14070-5. doi: 10.1523/JNEUROSCI.2690-15.2015

Sheridan DC, Hughes AR, Erdelyi F, Szabo G, Hentges ST, Schoppa NE. 2014. Matching of feedback inhibition with excitation ensures fidelity of information flow in the anterior piriform cortex. Neuroscience 275:519-30. doi: 10.1016/j.neuroscience.2014.06.033

Silberberg G, Markram H. 2007. Disynaptic inhibition between neocortical pyramidal cells mediated by Martinotti cells. Neuron 53:735-46. doi: 10.1016/j.neuron.2007.02.012

Stern M, Bolding KA, Abbott LF, Franks KM. 2018. A transformation from temporal to ensemble coding in a model of piriform cortex. Elife 7:1-26. doi: 10.7554/eLife. 34831

Stettler DD, Axel R. 2009. Representations of odor in the piriform cortex. Neuron 63:854-64. doi: 10.1016/j.neuron.2009.09.005 
1064

1065

1066

1067

1068

1069

1070

1071

1072

1073

1074

1075

1076

1077

1078

1079

1080

1081

1082

1083

1084

1085

1086

1087

1088

1089

1090

1091

1092

1093

1094

1095

1096

1097

1098

1099

1100

1101

1102

1103

1104

1105

1106

1107

1108

1109

1110

1111

1112

Stokes CC, Isaacson JS. 2010. From dendrite to soma: dynamic routing of inhibition by complementary interneuron microcircuits in olfactory cortex. Neuron 67:452-65. doi: 10.1016/j.neuron.2010.06.029

Stokes CC, Teeter CM, Isaacson JS. 2014. Single dendrite-targeting interneurons generate branch-specific inhibition. Front Neural Circuits 8:139. doi: 10.3389/fncir.2014.00139

Sturgill JF, Isaacson JS. 2015. Somatostatin cells regulate sensory response fidelity via subtractive inhibition in olfactory cortex. Nat Neurosci 18:531-535. doi: 10.1038/nn.3971

Suzuki N, Bekkers JM. 2006. Neural coding by two classes of principal cells in the mouse piriform cortex. $J$ Neurosci 26:11938-47. doi: 10.1523/JNEUROSCI.3473-06.2006

Suzuki N, Bekkers JM. 2010a. Distinctive classes of GABAergic interneurons provide layer-specific phasic inhibition in the anterior piriform cortex. Cereb Cortex 20:2971-2984. doi: 10.1093/cercor/bhq046

Suzuki N, Bekkers JM. 2010b. Inhibitory neurons in the anterior piriform cortex of the mouse: Classification using molecular markers. J Comp Neurol 518:1670-1687. doi: $10.1002 /$ cne. 22295

Suzuki N, Bekkers JM. 2012. Microcircuits mediating feedforward and feedback synaptic inhibition in the piriform cortex. J Neurosci 32:919-31. doi: 10.1523/JNEUROSCI.4112-11.2012

Suzuki N, Tang CS-M, Bekkers JM. 2014. Persistent barrage firing in cortical interneurons can be induced in vivo and may be important for the suppression of epileptiform activity. Front Cell Neurosci 8:76-86. doi: 10.3389/fncel.2014.00076

Tamamaki N, Yanagawa Y, Tomioka R, Miyazaki J, Obata K, Kaneko T. 2003. Green fluorescent protein expression and colocalization with calretinin, parvalbumin, and somatostatin in the GAD67-GFP knock-in mouse. J Comp Neurol 467:6079. doi: 10.1002/cne.10905

Tantirigama MLS, Huang HH-Y, Bekkers JM. 2017. Spontaneous activity in the piriform cortex extends the dynamic range of cortical odor coding. Proc Natl Acad Sci USA 114:2407-2412. doi: 10.1073/pnas.1620939114

Tischbirek C, Birkner A, Jia H, Sakmann B, Konnerth A. 2015. Deep two-photon brain imaging with a red-shifted fluorometric $\mathrm{Ca}^{2+}$ indicator. Proc Natl Acad Sci USA 112:11377-82. doi: 10.1073/pnas.1514209112

Toni N, Buchs P-A, Nikonenko I, Bron CR, Muller D. 1999. LTP promotes formation of multiple spine synapses between a single axon terminal and a dendrite. Nature 402:421-425. doi: 10.1038/46574

Tonnesen J, Katona G, Rozsa B, Nagerl UV. 2014. Spine neck plasticity regulates compartmentalization of synapses. Nat Neurosci 17:678-85. doi: 10.1038/nn.3682

Tremblay R, Lee S, Rudy B. 2016. GABAergic interneurons in the neocortex: From cellular properties to circuits. Neuron 91:260-292. doi: 10.1016/j.neuron.2016.06.033

Tseng G-F, Haberly LB. 1989. Deep neurons in piriform cortex. I. Morphology and synaptically evoked responses including a unique high-amplitude paired shock facilitation. J Neurophysiol 62:369-385. doi: 10.1152/jn.1989.62.2.369

Uchida N, Mainen ZF. 2003. Speed and accuracy of olfactory discrimination in the rat. Nature Neurosci. 6:1224-1229. doi: 10.1038/nn1142 
1113

1114

1115

1116

1117

1118

1119

1120

1121

1122

1123

1124

1125

1126

1127

1128

1129

1130

Wesson DW, Borkowski AH, Landreth GE, Nixon RA, Levy E, Wilson DA. 2011. Sensory network dysfunction, behavioral impairments, and their reversibility in an Alzheimer's beta-amyloidosis mouse model. J Neurosci 31:15962-71. doi: 10.1523/JNEUROSCI.2085-11.2011

Willmore B, Tolhurst DJ. 2001. Characterizing the sparseness of neural codes. Network 12:255-70. doi: 10.1080/net.12.3.255.270

Wilson DA. 2010. Single-unit activity in piriform cortex during slow-wave state is shaped by recent odor experience. $J$ Neurosci 30:1760-5. doi: 10.1523/JNEUROSCI.5636-09.2010

Wilson DA, Stevenson RJ 2006. Learning to Smell: Olfactory Perception from Neurobiology to Behavior, Baltimore, MD, The Johns Hopkins University Press.

Zeng H, Sanes JR. 2017. Neuronal cell-type classification: challenges, opportunities and the path forward. Nat Rev Neurosci 18:530-546. doi: 10.1038/nrn.2017.85

Zhan C, Luo M. 2010. Diverse patterns of odor representation by neurons in the anterior piriform cortex of awake mice. $J$ Neurosci 30:16662-72. doi: 10.1523/JNEUROSCI.4400-10.2010 
Suzuki et al - p 48

\section{Figure legends}

1133 Figure 1. Layer 1a neurogliaform (NG) and horizontal (HZ) cells are reliably 1134 distinguished using two-photon-targeted patch clamping in vivo. NG and HZ 1135 cells respond differently to odors. A, Schematic showing two forms of synaptic 1136 inhibition received by principal cells $(\mathrm{Pr})$ in the PCx: feedforward (red, mediated 1137 by NG and HZ cells in layer 1a [L1a]) and feedback (blue, mediated by fast1138 spiking [FS] and regular-spiking [RS] cells in L3). Feedback inhibition from 1139 other cell types (e.g. bitufted cells, deep NG cells) is not shown. LOT, lateral 1140 olfactory tract; aff, afferent layer; assn, associational layers. B (top), 2-photon 1141 images from a GAD67-GFP ( $\Delta$ neo) mouse showing (arrowed, left) the very 1142 bright GFP fluorescence in a NG cell and the much weaker GFP in a HZ cell 1143 (arrowed, right; arrowhead indicates a nearby NG cell). B (bottom), z-projection 1144 of the same two cells imaged in the red channel; internal solution contained Alexa 1145 Fluor-594. Dashed yellow lines show approximate position of patch electrode. 1146 Scale bar (bottom right) applies to all panels. C, Responses of NG cell (left) and

1148 Comparison of selected properties of action potentials recorded in NG and HZ 1149 cells in response to current steps in vivo. Points show data from individual 1150 neurons, bars show mean \pm SEM. **, $p<0.01, n=33$ for NG, $n=11$ for HZ, 1151 Welch 2-sample unpaired t-test. E, Response of a NG cell to a palette of 15 1152 structurally-diverse odors (name under each trace). Application period is shown 1153 by the red bar. Similar results were obtained from a total of 28 NG cells. F, 1154 Recordings made from a HZ cell. Similar results were obtained from $10 \mathrm{HZ}$ cells. 1155 Further details on analyzing these odor responses are in Figure 1 - Figure $1156 \quad$ Supplement 1. 
Suzuki et al - p 49

1158 Figure 2. Oscillations in membrane potential $\left(V_{m}\right)$ are synchronized to respiration in 1159 NG and HZ cells, and the oscillation amplitude is enhanced in NG cells during 1160 odors. A (top), Response of a NG cell to ethyl-n-butyrate. Gray trace below 1161 shows the respiration. A (bottom), Indicated time windows are shown expanded, with the traces in 3 consecutive sub-windows shown superimposed: $b$, before odor application; $d$, during; $a$, after. B, Same for the response of a HZ cell to ethyl-n-butyrate. C, Summary of measurements from the NG cell in panel A when applying 12 different odors. Plots show peak-to-peak amplitude of mean $V_{m}$ (left) and location of peak mean $V_{m}$ expressed as phase of respiration cycle (right), each averaged over $\sim 10$ respiration cycles occurring in a 3 s-long window before, during or after odor application. Lines connect measurements made in the same sweep for each of the 12 odors. D, Summary of mean peak-to-peak $V_{m}$ amplitudes (left) and phase (right) measured as in panel $\mathbf{C}$, averaged over $n=22$ NG cells and $n=10 \mathrm{HZ}$ cells. Black, red and blue bars show mean \pm SEM before, during and after odor application, respectively. ***, $p<0.001 ; * *, p<0.01 ; n s$, not significant; ANOVA. Similar results were obtained using an alternative approach, cross-covariance analysis (Figure 2 - Figure Supplement 1). In contrast, respiration-synchronized oscillations in $V_{m}$ were not observed in an NG cell in the primary somatosensory cortex (Figure 2 - Figure Supplement 2).

1178 Figure 3. NG cells tend to fire earlier than $\mathrm{HZ}$ cells in response to odors. A (top), Spike raster plots for NG cells (left) and HZ cells (right) in our dataset that fired at least one AP before, during or after odor application $(n=98$ trials in 8 NG cells, $n=86$ trials in $6 \mathrm{HZ}$ cells). Different colors indicate different cells. Gray 

histograms (PSTHs) for the raster plots, showing the greater delay to odor-evoked firing in $\mathrm{HZ}$ cells. These responses were not limited by the rate of delivery of odorants by our olfactometer (Figure 3 - Figure Supplement 1). B (top), 2photon images of GFP (green) and Cal-590 (red) fluorescence for a layer 1a NG cell (left, arrowhead) and a HZ cell (right, arrowhead). B (bottom), Averaged $\Delta \mathrm{F} / \mathrm{F}_{0}$ plots for the somatic responses of $n=6 \mathrm{NG}$ cells (left) and $n=5 \mathrm{HZ}$ cells (right) in response to odor. Similar results were observed using alternative anesthesia that produces a more awake-like state (Figure 3 - Figure

\section{Supplement 2)}

1193 Figure 4. Odors cause $V_{m}$ to depolarize more slowly in $\mathrm{HZ}$ cells than in NG cells. A, 1194 Averaged in vivo current clamp recordings of odor-evoked EPSPs measured in 1195 NG cells (left, $n=16$ cells) and HZ cells (right, $n=6$ ). Inset (bottom) shows the 1196 same traces normalized to their peaks, overlaid and expanded, showing that 1197 averaged EPSPs in HZ cells have a slower time to peak. To facilitate comparison, 1198 these EPSPs were filtered to remove respiration-linked oscillations (Figure 4 -

1199 Figure Supplement 1). B (top), Response of a NG cell to ethyl-n-butyrate 1200 (left) and a HZ cell to 1-heptanal (right). The corresponding respiration trace is shown below (gray). B (bottom), z-score-transformed mean $V_{m}$ amplitude (averaged over each respiration cycle) calculated for the same two neurons as above. Spikes were removed before measuring $V_{m}$. Upper horizontal dashed line indicates the detection threshold $(z$-score $=2.5)$ for an odor-evoked response. Superimposed red (left) or blue (right) line represents a linear fit to the data points 

data point represents the odor response of a single cell (red symbols, $n=310$ responses from $28 \mathrm{NG}$ cells; blue symbols, $n=188$ responses from $9 \mathrm{HZ}$ cells). Points below the threshold for an odor-evoked response $(\mathrm{z}$-score $=2.5)$ have been grayed out. C (bottom), Probability density function (PDF) of the points plotted in panel $\mathbf{C}$ (top), excluding the grayed-out values. NG cells (red plot) show a significant skew towards negative slopes, whereas HZ cells (blue) skew towards

1217 Figure 5. Differences in EPSC kinetics partly account for the different odor positive slopes ( $p<0.001$; Kolmogorov-Smirnov test). responsiveness of $\mathrm{NG}$ and $\mathrm{HZ}$ cells $\mathbf{A}$, Schematic showing the circuit dynamics that are proposed to explain the results in Figure 4, viz. LOT input onto NG and HZ cells is hypothesized to be depressing and facilitating, respectively. SP, superficial pyramidal cell. B, Slice experiments showing EPSPs elicited in NG cells and HZ cells in response to trains of extracellular stimuli applied to the LOT. B (top), Six stimuli at $40 \mathrm{~Hz}$ elicit facilitating EPSPs in an NG cell (left) but depressing EPSPs in an HZ cell (right), which is opposite to the hypothesized responses (panel A). B (bottom), A longer train ( 9 bursts of $40 \mathrm{~Hz}$ trains, repeated at $3 \mathrm{~Hz}$ ), thought to more closely replicate odor-evoked stimuli, elicits a depressing envelope of EPSPs in both an NG cell (left) and an HZ cell (right). Thus, the hypothesis in panel $\mathbf{A}$ is supported for NG cells but not for HZ cells. Stimulus artefacts are blanked. Similar results were obtained in $n=6$ experiments of this kind for each cell type. C, Averaged in vivo voltage clamp recordings of odor-evoked EPSCs measured in NG cells (left, $n=17$ cell-odor pairs) and HZ 

HZ cells have a slower time to peak.

1236 Figure 6. $\mathrm{NG}$ and $\mathrm{HZ}$ cells receive odor-evoked feedforward inhibition, predominantly from other NG cells. A, Averaged in vivo voltage clamp recordings of odor-evoked IPSCs measured in NG cells (left, $n=14$ cell-odor pairs) and $\mathrm{HZ}$ cells (right, $n=5$ cell-odor pairs). Holding potential $+10 \mathrm{mV}$. In separate experiments it was found that synaptic inhibition could also be observed in HZ cells under current clamp (Figure 6 - Figure Supplement 1). B, Dual recording from a synaptically-connected $\mathrm{NG}$ cell and $\mathrm{HZ}$ cell pair in a slice. Stimulus was a $20 \mathrm{~Hz}$ train of 2 ms-long depolarizing current steps applied to the NG cell. Postsynaptic response is an average of 15 episodes (holding potential, connections/total number tested'. ${ }^{*}, p<0.05$, Chi square $2 \times 2$ contingency test.

1249 Figure 7. NG and HZ cells produce different patterns of synaptic inhibition in 1250 postsynaptic SP cells. A, Average IPSPs recorded in vitro in a SP cell (black 1251 traces; stimulus artefacts blanked) in response to extracellular stimulation in layer la of the slice, using spiking patterns that had previously been recorded in vivo in either NG cells (left) or HZ cells (right). Examples of these spiking patterns are shown in the red traces (top). IPSPs were averaged from $n=6 \mathrm{SP}$ cells, to each of which was applied up to 16 different stimulus patterns (NG and HZ). To preserve possible respiration-synchronized effects (Figure 2) when averaging 
across different stimulus patterns, each raw IPSP trace was linearly warped to match a reference respiration trace (gray, bottom). B (top), Example action potentials recorded in SP cells while using a dynamic clamp to inject an odorevoked excitatory postsynaptic conductance (EPSG) that had previously been recorded in vivo. Responses with the EPSG alone (upper traces, black) were interleaved with responses to the EPSG plus extracellular synaptic stimulation (lower traces, blue; stimulus artefacts blanked) driven by different odor-evoked spiking patterns for NG cells (left) or $\mathrm{HZ}$ cells (right). As in panel A, stimulus patterns were linearly warped to a reference respiration trace. Asterisks above the upper traces label action potentials that are absent in the lower traces. All slice recordings in panels $\mathbf{A}$ and $\mathbf{B}$ were made in the presence of $20 \mu \mathrm{M}$ CNQX and $25 \mu \mathrm{M}$ D-AP5. B (bottom), Mean normalized PSTH plots from $n=7 \mathrm{SP}$ cells showing that synaptic inhibition patterned on NG cell activity significantly suppresses early firing in SP cells (left), whereas inhibition patterned on HZ cell firing has a weak, delayed effect (right). Gray bars in panels $\mathbf{A}$ and $\mathbf{B}$ indicate the period during which odor was applied in the in vivo recordings from NG and HZ cells. 
A
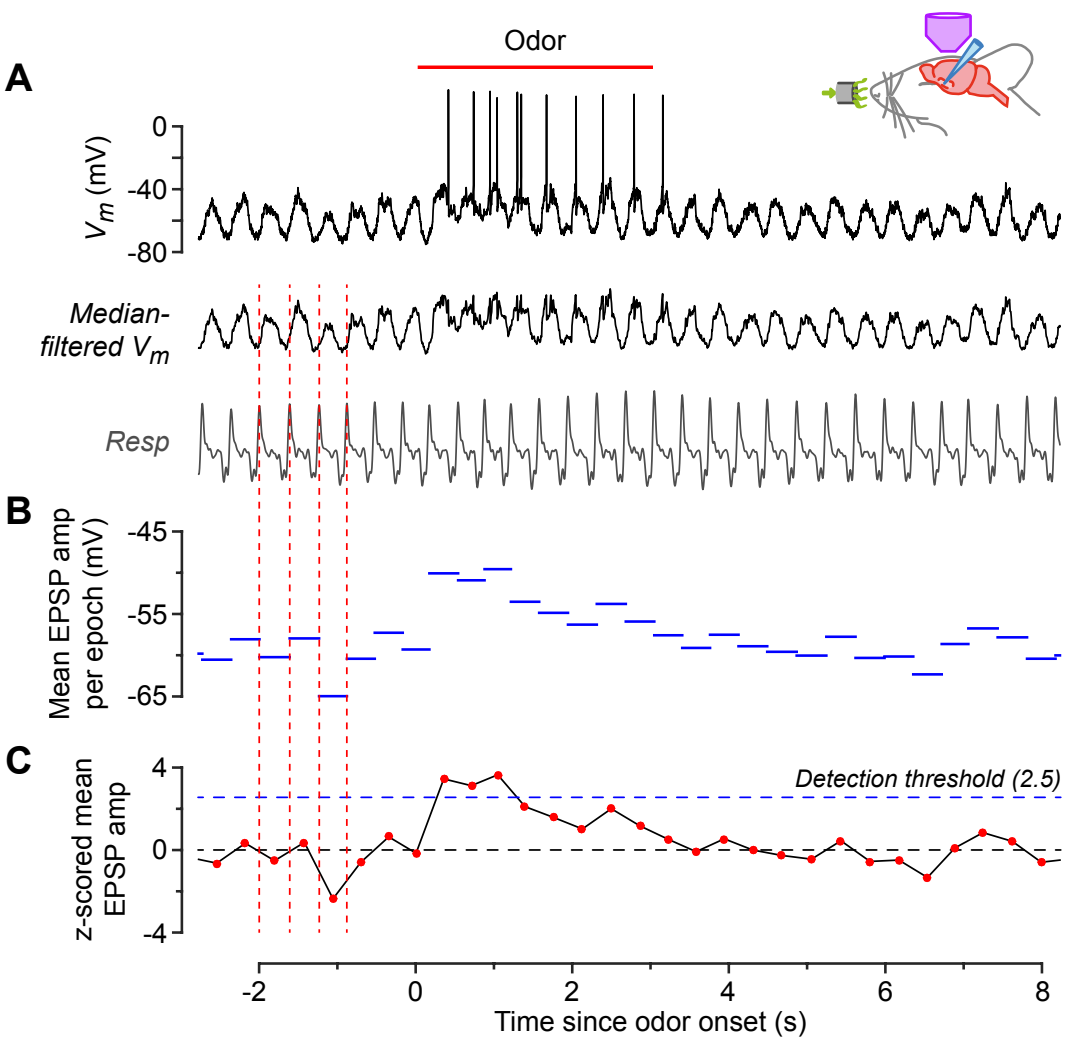

Figure 1 - Figure Supplement 1. Measurement of odor responsiveness.

This example shows the response of a NG cell to ethyl-n-butyrate. A, Raw membrane potential $\left(V_{m}\right)$ (top), and $V_{m}$ after median filtering to remove action potentials (middle). Bottom trace is the concurrently-recorded respiration. Peaks in the respiration trace (corresponding to exhalation) were detected (vertical dashed red lines) and the time between consecutive peaks was designated a 'respiration epoch'. B, Mean amplitude of the median-filtered $V_{m}$, averaged over each respiration epoch. C, z-scored version of the data in panel $\mathbf{B}$. This was calculated by normalizing each point to the mean and standard deviation of the data points in $\mathbf{B}$ that occurred during the baseline period, i.e. during the 8 seconds prior to odor application. If the z-score exceeded a detection threshold of 2.5 (horizontal dashed blue line) at any time during the odor application period, then an odor response was counted. This cell responded to 14 out of 15 odors so its odor response index was $14 / 15=0.93$. Each odor was applied only once to avoid habituation. 
A

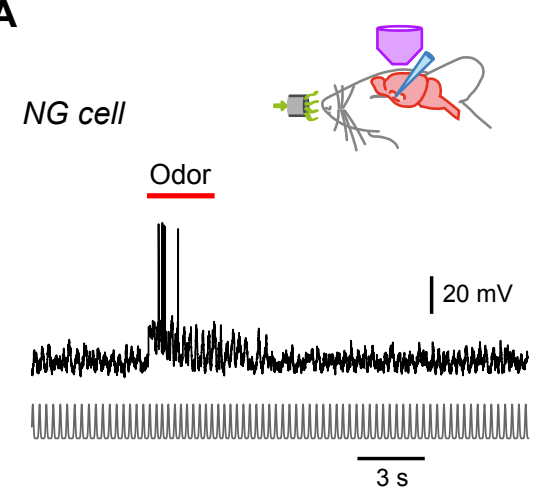

C

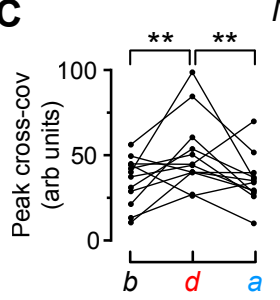

NG cell

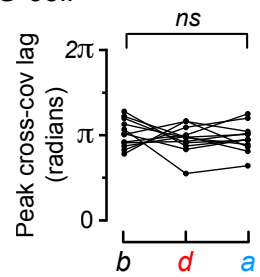

B

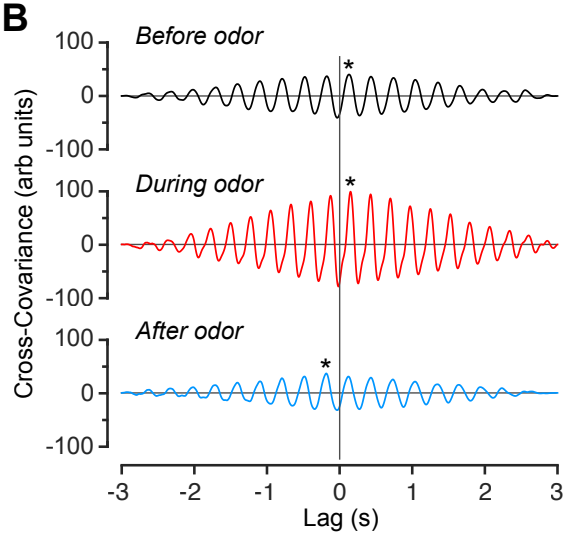

D

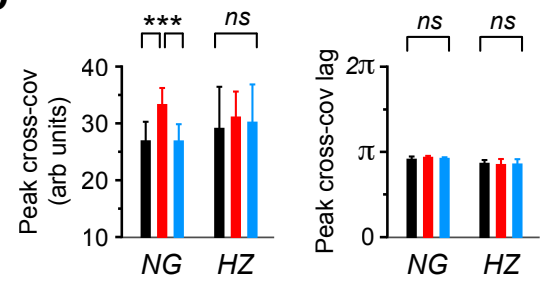

Figure 2 - Figure Supplement 1. Cross-covariance analysis confirms the presence of respiration-locked oscillations in $V_{m}$ in NG and $\mathrm{HZ}$ cells, with the amplitude of these oscillations increasing in NG cells during odors.

A, Same NG cell as in Figure 2A, except that the respiration trace has been replaced by a normalized series of Gaussians representing the peaks in the respiration cycles (bottom). This was done to allow us to compare the cross-covariance between different cells by eliminating differences in the amplitude or shape of the respiration trace. B, Cross-covariance between $V_{m}$ and the Gaussian-normalized respiration for the cell in panel A, calculated for $3 \mathrm{~s}$-long windows starting $6 \mathrm{~s}$ before, $0.5 \mathrm{~s}$ after and $16 \mathrm{~s}$ after odor onset, respectively. Asterisks indicate the peak cross-covariance found within \pm 0.3 s (approximately \pm 1 respiration cycle) of the zero lag time. C, Changes in peak cross-covariance amplitude (left) and lag (right) before $(b)$, during $(d)$ and after $(a)$ odor application for the cell in panel $\mathbf{A}$. Each triplet of connected points represents data obtained when applying a different odor to this cell. D, Summary of average peak cross-covariance amplitude (left) and lag (right) for $22 \mathrm{NG}$ cells and $9 \mathrm{HZ}$ cells. Bars show mean \pm SEM (black, before odor; red, during; blue, after). ${ }^{* * *}, p<0.001$; ${ }^{* *}, p<$ $0.01 ; n s$, not significantly different; 1-way ANOVA with Tukey. 
A

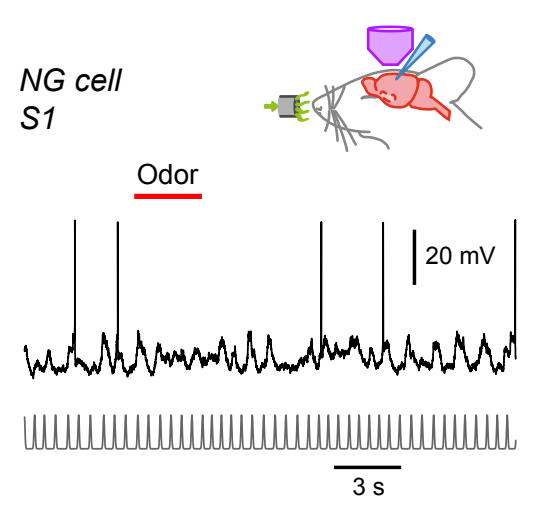

B

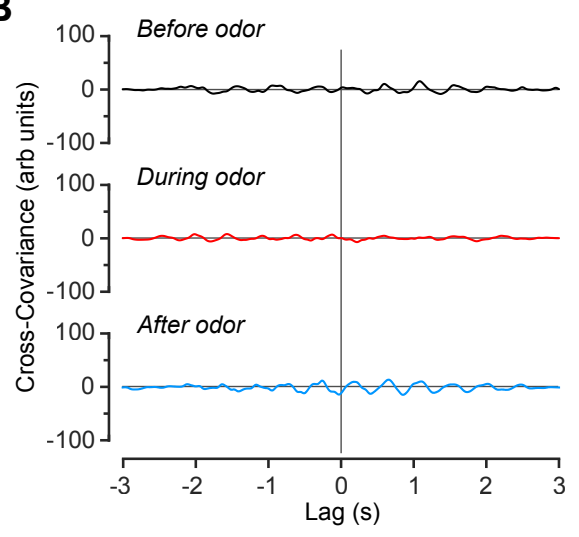

C

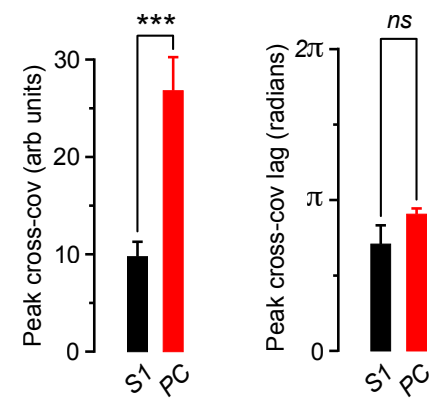

Figure 2 - Figure Supplement 2. Subthreshold membrane potential $(\mathrm{Vm})$ in NG cells in the primary somatosensory cortex (S1) does not oscillate in phase with respiration and does not respond to odors, in contrast to NG cells in the piriform cortex (PCX).

A, Recording from an S1 NG cell while applying odor (here, lavender; red bar). Trace at bottom is a normalized series of Gaussians representing the peaks in the respiration cycles, as in Figure S2. B, Cross-covariance between $V_{m}$ and the Gaussian-normalized respiration for the cell in panel $\mathbf{A}$, calculated for $3 \mathrm{~s}$-long windows starting $6 \mathrm{~s}$ before, 0.5 $\mathrm{s}$ after and $16 \mathrm{~s}$ after odor onset, respectively. Traces are displayed on the same axes as for the piriform NG cell in Figure S2B to facilitate comparison. Note the much weaker cross-covariance for this NG cell in S1. C, Average peak cross-covariance amplitude (left) and lag (right) for the S1 NG cell in panels $\mathbf{A}$ and $\mathbf{B}$ ( $n=11$ trials) compared with the PCx NG cells $(n=22)$ in Figure S2D. ${ }^{* * *}, p<0.001$; $n s$, not significantly different; Welch 2-sample unpaired t-test. 


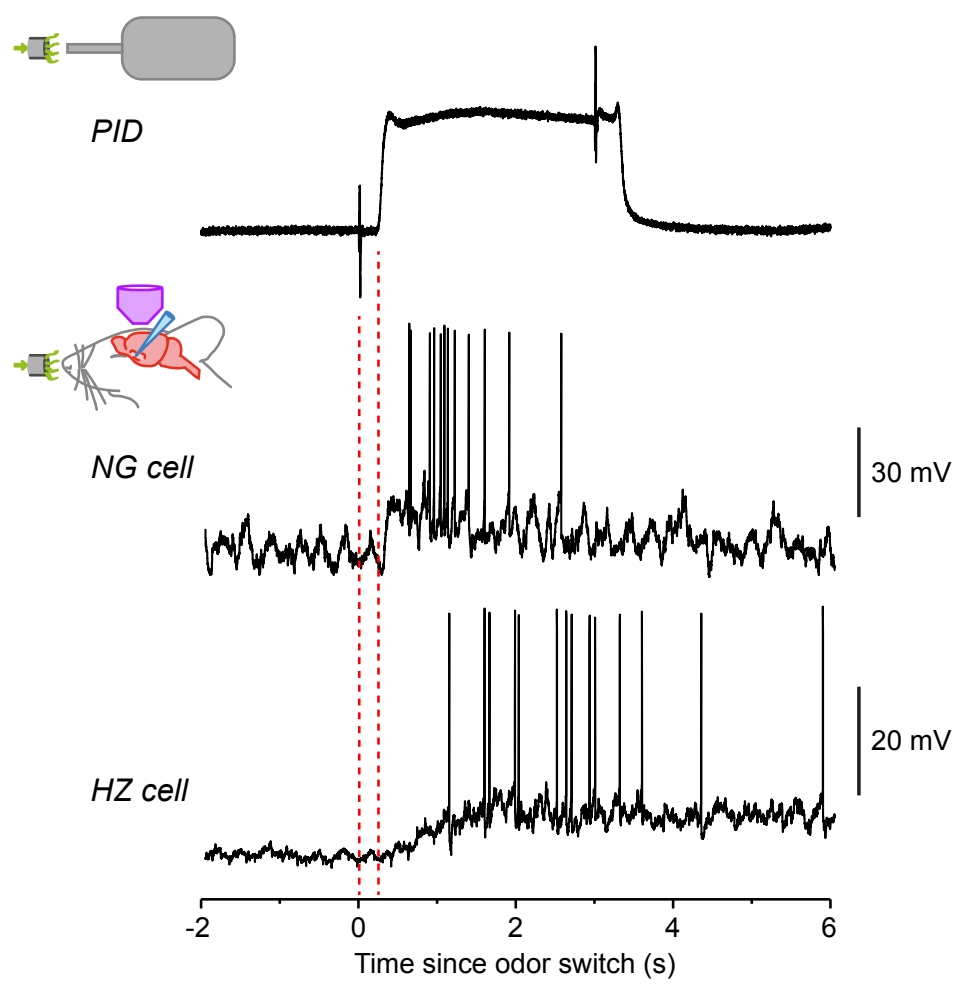

Figure 3 - Figure Supplement 1. Response of HZ cells, but not NG cells, is much slower than the speed of odor arrival.

Top trace shows the odor application kinetics for our olfactometer, as measured using a photoionization detector (PID). The brief transients at times 0 and $3 \mathrm{~s}$ are due to the opening and closing, respectively, of the valve in the olfactometer. Note the delay to odor onset (242 $\pm 6 \mathrm{~ms}, n=9$ odors measured), and a similar delay at odor offset. (All data presented in this paper were corrected for this delay.) The $20-80 \%$ rise time of the odor arrival was $46 \pm 2 \mathrm{~ms}(n=9)$. The lower two traces show example recordings from a NG cell and a HZ cell, plotted on the same time scale as the PID trace. The NG cell response rises as rapidly as the odor onset, whereas the $\mathrm{HZ}$ response is delayed. These examples are taken from Figure 1 (1-heptanal). 
A
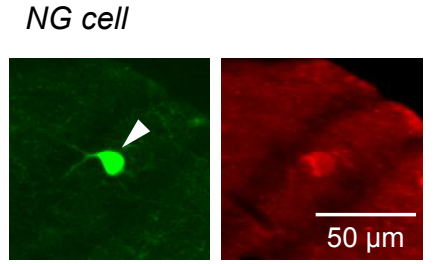

B

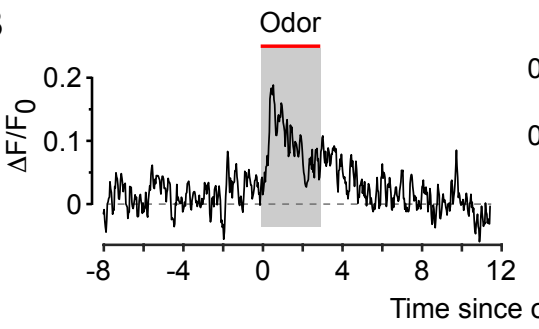

$H Z$ cell
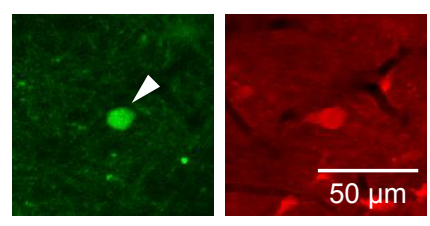

Odor

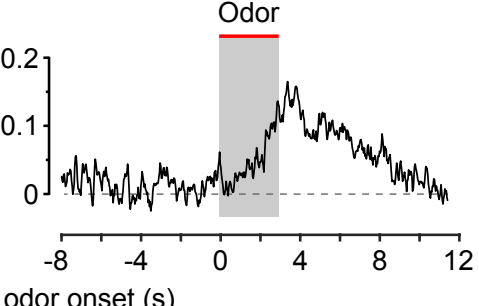

Figure 3 - Figure Supplement 2. In vivo 2-photon calcium imaging experiments confirm that NG and $\mathrm{HZ}$ cells respond similarly to odors in animals anesthetized with either urethane or fentanyl and medetomidine.

A, In vivo two-photon images of GFP (green, arrowhead) and resting Cal-590 fluorescence (red, arrowhead) in a NG cell (left) and $\mathrm{HZ}$ cell (right). B, Average $\Delta \mathrm{F} / \mathrm{F} 0$ responses in $n=3 \mathrm{NG}$ cells (left) and $n=5 \mathrm{HZ}$ cells (right), recorded under fentanyl + medetomidine anesthesia. Odor was applied for the $3 \mathrm{~s}$ period indicated. The response kinetics are similar to those recorded under urethane anesthesia (Figure 3B). 


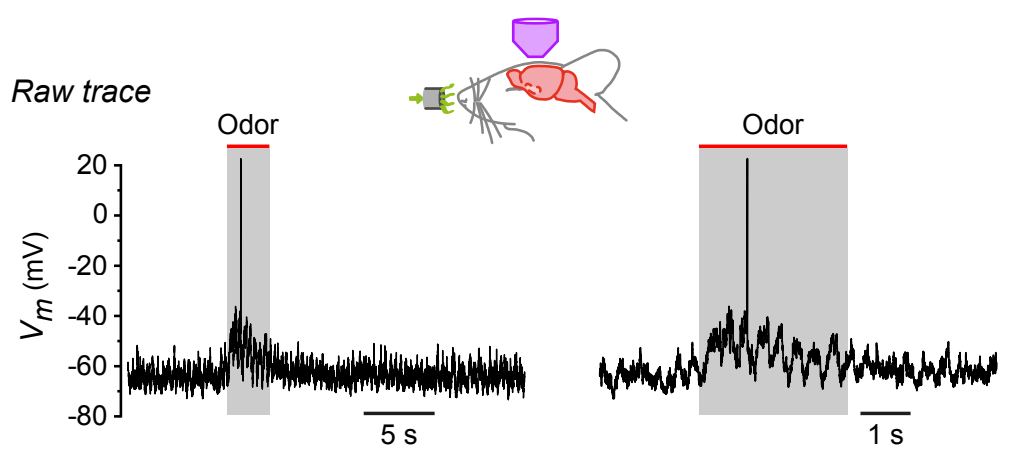

Median filtered
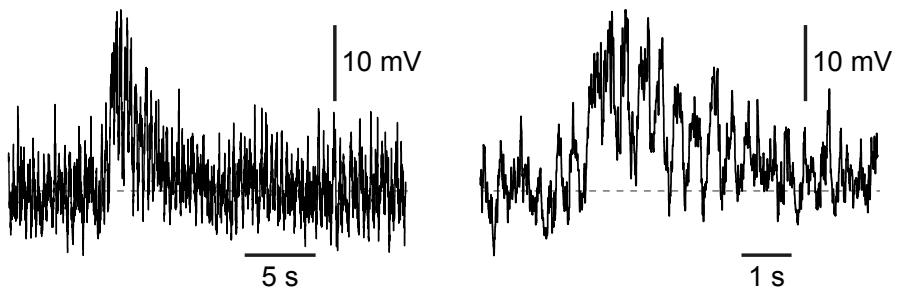

Notch filtered
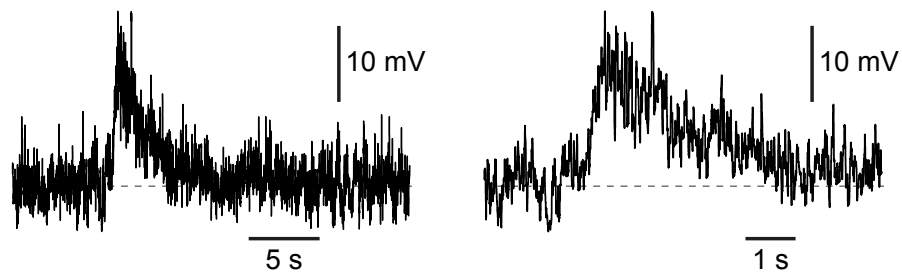

Averaged and fitted
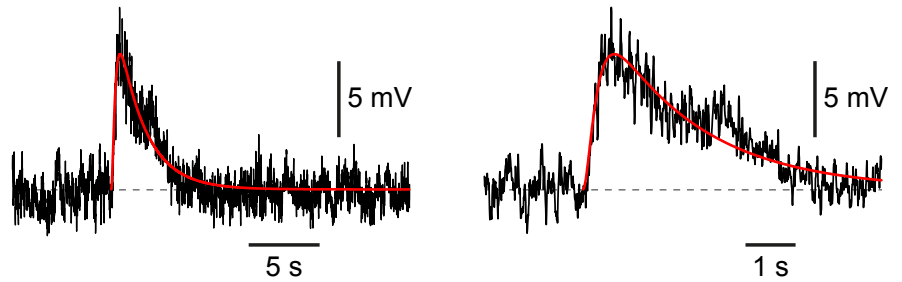

Figure 4 - Figure Supplement 1. Procedure for measuring the properties of odor-evoked EPSPs.

Traces show, from top to bottom, the cumulative effect of each step in the analysis. Each row shows the same trace on two different timescales. Raw trace, response of a NG cell to lavender. Median filtered, same trace after median filtering to remove the action potential. Notch filtered, same trace after notch filtering at 2-4 $\mathrm{Hz}$ to remove the respiration-synchronized oscillations in $V_{m}$. Averaged and fitted, average of responses of this cell to 8 different odorants, each response filtered as above, then fitted to a smooth function of the form $m^{2} h$ (superimposed red curve). The mean EPSP time to peak and halfwidth were measured from the fitted curve. 


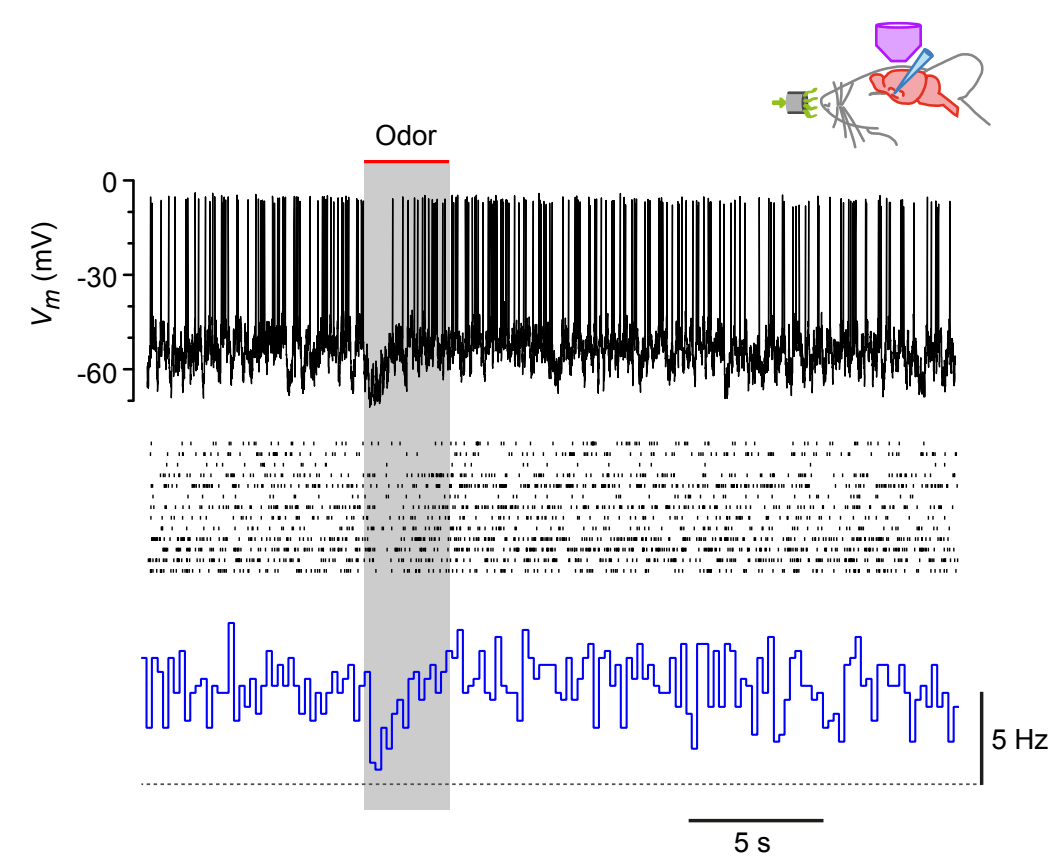

Figure 6 - Figure Supplement 1. Steady depolarization of a $\mathrm{HZ}$ cell in vivo reveals odor-evoked hyperpolarization and suppression of firing.

Recordings from a $\mathrm{HZ}$ cell that has been depolarized by steady current injection then presented with 13 different odors. Top, example showing the transient inhibition of spiking during odor presentation (here, lavender). Middle, raster plots from all 13 odor presentations to this cell. Bottom, PSTH of the data in the middle panel, showing that the steady spiking $(\sim 5 \mathrm{~Hz})$ is transiently inhibited by odor. Horizontal dashed line indicates $0 \mathrm{~Hz}$ baseline. 